\title{
Yeni Ürün Gruplarının Oluşturulmasında Grafik Tasarımın Etkisi
}

\section{The Influence of Graphic Design in Creating New Product Groups}

\section{Damla Tuğrul}

Grafik Tasarım Bölümü Yüksek Lisans Öğrencisi, Ankara Hacı Bayram Veli Üniversitesi Sanat ve Tasarım Fakültesi Güzel Sanatlar Enstitüsü

email: tugruldamla@gmail.com DORCID ID: https://orcid.org/0000-0003-3357-7781

\section{Gültekin Akengin}

Prof. Dr., Ankara Hacı Bayram Veli Üniversitesi Sanat ve Tasarım Fakültesi Görsel Sanatlar Bölümü email: gultekinakengin@gmail.com (DORCID ID: https://orcid.org/0000-0002-5399-2731

$\checkmark$ iThenticate" ${ }_{\text {for Authors \& hesearchers }}$ Bu makale bilimsel etik ve kurallara uygun hazırlanmış ve intihal incelemesinden geçirilmiştir

Atıf (APA 6)/Tocitethisarticle

Tuğrul, D., \& Akengin, G. (2020). Yeni ürün gruplarının oluşturulmasında grafik tasarımın etkisi. Atatürk Üniversitesi Güzel Sanatlar Enstitüsü Dergisi, 26(44), 269-286. doi: https://doi.org/10.35247/ataunigsed.673016

Makale Gönderim Tarihi/Received: 24/12/2019

Makale Kabul Tarihi/Accepted: 29/02/2020

Makale Yayın Tarihi/Published: 19/03/2020

Research Article / Araștırma Makalesi

$\ddot{\mathbf{O z}}$

Araștırma konusu olarak, yeni ürün gruplarının olușturulmasında grafik tasarımın etkisi ele alınmıştır. Bu konu ile pazarda bulunan endüstriyel ürünlerde hangi grafik tasarım unsurlarının bulunduğu, nasıl kullanıldığ1 ve benzerlerinden nasıl farklılaştığ1 tespit edilmesi amaçlanmıştır. Literatür aracılığıyla benzer konularda yapılan araștırmalar incelenerek endüstriyel tasarım, grafik tasarım ve pazarlama disiplinleri tanımlanmıştır. Smeg, Gorenje, Samsung, Arçelik, Vestel gibi 10 adet beyaz esya üretimcisi firmanın yurtiçi ve yurtdışı pazarlarına ait buzdolabı serileri yazılı ve görsel malzeme taraması ile toplanarak incelenmiștir. İncelenen markalara ait toplamda 26 seri örnek görselleri ile birlikte sunulmuştur.

Rekabetin ve teknolojik gelișmenin yoğun olduğu günümüz pazarlarında endüstriyel ürünlerin benzerlerinden farklılaşması gerekmektedir. Analiz, tasarım, üretim, pazarlama, müşteri memnuniyeti gibi birçok aşamayı içeren ürün yaratım ve sunum sürecinde bu farklılaşmanın en az maliyetle en fazla kalite ve ilgi çekiciliği yakalayabilmesi ürünün bașarısını meydana getirmektedir. $\mathrm{Bu}$ bağlamda incelenen ürünlerde malzemenin, formun, rengin, tipografinin ve illüstrasyonun tasarıma etkileri değerlendirilmiștir. Hedef kitle, günümüz moda ve mobilya trendleri, marka iş birlikleri, kullanım alanları gibi özelleştirilerek oluşturulan serilerdeki unsurların daha bilinçli ve etkin tasarlandığı ortaya konulmuș ve böyle tasarımların piyasada rakiplerine kıyasla daha öne çıktığı görülmüştür.

İncelenen buzdolapları ve tasarım unsurlarından sonuçla "Anadolu" markası oluşturulmuş ve Türkiye'nin yedi bölgesine ait geleneksel kıyafetlerden yola çıkılarak 7 seri ve 39 buzdolabı tasarımı örneği ortaya koyulmuștur.

Anahtar kelimeler: : Endüstriyel Tasarım, Disiplinlerarası Etkileşim, Grafik Tasarımı, Ürün Pazarlaması, Yeni Ürünler

\begin{abstract}
As a research topic, "the Influence of Graphic Design on the Creation of New Product Groups" has been discussed. It is aimed to determine which graphic design elements exist in the industrial products on the market, how they are used and how they differ from the others. Industrial design, graphic design and marketing disciplines are defined by examining the researches on similar subjects through literature. Written and visual materials of ten white goods which are Smeg, Gorenje, Samsung, Arcelik and Vestel refrigerator series belonging to the domestic and foreign markets were collected and examined. A total of 26 series of the brands are presented with sample images.

In today's markets where competition and technological development are intense, industrial products need to differentiate from their peers. The success of the product is the fact that this differentiation in the product creation and presentation process, which includes many stages such as analysis, design, production, marketing, customer satisfaction, achieves the highest quality and attractiveness at the lowest cost. In this context, the effects of material, form, color, typography and illustration on the design were evaluated. It has been demonstrated that the elements in the series created by customizing the target audience, today's fashion and furniture trends, brand collaborations and usage areas are designed more consciously and effectively and it is seen that such designs are more prominent in the market than their competitors.
\end{abstract}

As a result of the investigation of refrigerators and design elements, "Anadolu" brand was created and influencing by the traditional dress of the seven regions of Turkey, 7 series and 39 refrigerator design has been demonstrated.

Keywords: Graphic Design, İndustrial Design, İnterdisciplinary İnteraction, New Products, Product Marketing

\section{Giriş}

Latincede biçim vermek anlamına gelen designare sözcügünden gelen tasarım kelimesi Löbach (1976)'a göre, bir sorunun çözümü için oluşturulan plan anlamına gelmektedir (aktaran Tunalı, 2002, s. 81). Tasarım; bir hedefe yönelik planlamalardan oluşan, insanın meydana getirdiği biçimleri ve projeleri belirtmektedir.

Tasarım; bir hedefe yönelik planlamalardan oluşan, insanın meydana getirdiği biçimleri ve projeleri belirtmektedir. 
Tasarlama eylemi, başlarda el sanatları ve deneme yanılma yöntemi ile başlamıştır. Zaman içerisinde endüstrinin gelişmesiyle mimarlık ve sanat okulları açılmıştır. Taklitle başlayan bu dönem, el sanatı ile devam etmiştir. Bauhaus okulunun açılmasılyla daha sistematik bir anlayış yerleşmiş ve 1950'lerden sonra savaşın getirdiği etkilerle iş etüdü, ergonomi, sistem analizi gibi alanlarda kent planlama, mimarlık, endüstriyel tasarım gibi disiplinler öne çıkmaya başlamıştır. Bu tarihten sonra Bauhaus temellerine bağlı kalarak birçok bölüm açılmış ve kongreler yapılmıştır. Türkiye'de ise ilk defa 1973'te İstanbul Teknik Üniversitesi'nde Tasarlama Yönetim Kürsüsü’nün kuruluşu ile tasarıma dair bilimsel bir adım atılmıştır (Bayazıt, 1997, s. 1746-1747).

Tasarım, iki boyutlu olarak tabir edilen grafiksel iletişimden insanın etkileşimde bulunduğu üç boyutlu nesnelere kadar geniş bir alana sahiptir. İnsan düşüncesinin planlı olarak yeni ürünler yaratımı anlamına gelen bu sürecin amacı insanın yaşamını kolaylaştıran ürün ve iletişim ağı oluşturmayı sağlayabilmektir. Hasdoğan (1996) göre tasarım, genellikle pazardaki bir eksiklik, teknoloji gelişimiyle oluşan bir yenilik gibi nedenlerden dolayı oluşan ihtiyaçları karşılamak için yapılır (s. 24).

İngiliz filozof John Locke’a göre insan öğrenmelerinde gözlemlemenin yeri \%83'tür. Lidstorm'un araştırmalarında ise görme duyusunun satın alma kararını \%58 ile diğer duyulara göre daha fazla etkilediği vurgulanmaktadır (Durmaz, 2009, s. 138). İnsanın çevresini algılamak için kullandığı ilk yetisi görme duyusudur. Gördüğü bilgileri beyninde çevre, kültür, yaş gibi faktörler etkisinde işleyerek yorumlamaktadır. Buna göre rekabetin çok yoğun olduğu günümüz pazarında tasarımın estetiğinin ürünün satın alma başarısına etkisi büyük olarak görülmektedir. Sunulan ürünlerin ambalaj ve kabuk tasarımları endüstriyel tasarımın konusu olduğu kadar grafik tasarım alanına da girmektedir. Üretim maliyetleri, rekabet ortamı, uygun pazar ve sunum seçimi gibi pazarlama disiplininin konuları tasarım kararlarını etkileyen önemli unsurlardır. Bu sebeple bir ürün yaratımında bu üç disiplinin ilişkisi doğru bir süreçle yönetilebilirse müşteri tatminin oluşacağı başarılı bir ürün ortaya çıkacağı ön görülebilmektedir. Araştırmada ürün tasarımı, grafik tasarım ve pazarlama disiplinleri açıklanarak birbirileri ile etkileşimleri örneklendirilmiştir. Ayrıca grafik tasarımın uygulandığı endüstriyel ürünlerin maliyet ve pazarlama alanındaki avantajları belirtilerek benzer ürünlerden farklılaştığı ortaya konulmuştur.

Yeni teknolojilerin gelişimi, tüketicilerin beklentilerindeki değişimler ve rekabet fazlalığı gibi çevresel etkenlerin değişim hızı ürünlerin hayat seyrini kısaltmaktadır (Karsu, 2002, s. 5). Bundan dolayı işletmelerin daima kendini ön planda tutabilmek için mevcut ürünlerinin yerine koyacağı yeni ürünleri piyasaya sürmesi gerekmektedir. Firmalar açısından sürekli olarak yeni ürün oluşturmak, tasarım ve üretim faaliyetleri açısından uzun, karışık ve maliyetli bir süreç oluşturmaktadır. Bu sebeple daha akılcı ve etkili çözüm yöntemlerine gidilmektedir.

Pazardaki ürünlerde en sık yapılan yenilik çeşidi, var olan üründe iyileştirme ve var olan ürün hattına eklemeler yapma biçimindedir. Bu iki yöntemin toplamı yeni ürün çeşitlemelerinin \%52'sini oluşturmaktadır (İslamoğlu, 1999, s. 334). Görsel tasarım ve ambalajlama, bu açıdan değerlendirildiğinde ar-ge ve üretim faaliyetlerinde çok az değişiklik yapılarak büyük farklar elde edilmesini sağlayabilmektedir. $\mathrm{Bu}$ sebeple ürün niteliklerini değiştirmeden üründe yapılan ambalaj, giydirme, desen ve renk değişiklikleri tüketicinin farklı zamanlarda farklı beğenilerine hitap ederek az maliyetle çok etki yaratabilmektedir.

Araştırmanın amacı, pazardaki endüstriyel ürünlerinin yeni çıkan serilerinde hangi grafik tasarım öğelerinin bulunduğu ve benzerlerinden farklılaşmak için bu öğelerin nasıl kullanıldığının incelenmesidir. Bu sebeple araştırmanın ilk bölümünde benzer çalışmalar taranarak kavram tanımlamaları ve sonuç yorumlamaları yapılmıştır. İkinci aşamada çeşitlendirilmeye açık bir ürün grubu olarak buzdolapları seçilmiş ve piyasa örnekleri araştırılmıştır. Son olarak ise yapılan analizler yardımı ile buzdolabı tasarımları yapılmıştır.

Smeg, Gorenje, Samsung, Arçelik, Vestel gibi 10 adet beyaz eşya üretimcisi firmanın yurtiçi ve yurtdışı pazarlarına ait ürünlerinden yazılı ve görsel malzeme taraması ile toplanarak örnek olarak seçilen 26 adet ürün serisi, bulundurdukları tasarımsal unsurlar açısından incelenmiştir. Böylece endüstriyel ürünlerinin rakiplerinden sıyrılarak hangi tasarım unsurlarıyla farklılaştığının ve müşterilerin dikkatini nasıl çektiğinin ortaya koyulması amaçlanmıştır.

Uygulama bölümünde ise dikkat çekici, çok sayıda çeşitlilik barındıran ve geçmişle günümüzü birleştiren tasarımlar hedeflenerek geleneksel Türk kıyafetlerinden yola çıkan buzdolabı serileri oluşturulmuştur. Böylece Türk kültürüne ait çeşitli renk ve desenlerin farklı hedef kitleleri göz önünde bulundurularak tasarlanmasının ürünleri öne çıkarması amaçlanmıştır.

Araştırmanın önemi, gelişen teknolojilerle birlikte rekabetin zorlaştığı pazarlarda ürünlerin tasarımsal olarak hangi şekillerde öne çıktığının ortaya koyulmasıdır. Böylece tüketicinin ilgisini çekme ve ürünü satın aldırma yöntemi olarak yeni ürün serileri oluştururken endüstriyel tasarım ve grafik tasarım ortaklığının etkileri incelenmiştir. Grafik tasarımın ambalajsız satılan yanikendi reklamını sahip olduğu tasarım estetiğgi ile yapmak zorunda olan ürünlere getirdiği yenilik ve etkiler gözlemlenmektedir. Yaratılan farklılıklar incelenerek farklı 
disiplinlerin bir arada kullanımının önemi vurgulanmış ve böylece araştırmanın süreç ve sonucu piyasadaki ürün yaratma sürecindeki çalışmalara farklı bir yön ve bakış açısı sağlama acısından fayda sağlayacağı ön görülmüştür.

$\mathrm{Bu}$ çalışma kapsamında araştırılacak konunun sınırları; endüstriyel tasarım, grafik tasarım, yenilik, ürün kavramı, ürün geliştirme ve grafik tasarımın ürün pazarında etkin kullanım örneklerinin incelenmesi amacı ile belirlenmiştir. Neilsen Durables'ın yaptığı 2011 yılı Dayanıklı Tüketim Malları Araştırması'na göre, Türkiye'de kullanılan dayanıklı tüketim mallarının yüzde 36'sına sahip olan beyaz eşyalar önde gelmektedir. Bundan yola çıkılarak araştırma içerik ve örnekleri dayanıklı tüketim mallarından beyaz eşya grubunda yer alan buzdolabı tasarımları ile sınırlandırılmıştır.

Araştırmanın uygulama kısmında ise piyasada bulunan beyaz eşya firmalarının buzdolabı ürün serileri incelenmiş ve kullanılan grafik öğeleri dikkate alınarak yeni ürün serileri tasarlanmıştır.

Tasarlanan buzdolabı serilerinde kullanılan geleneksel kıyafetlerin çeşitliliği, günümüze aktarım farkları ve motiflerin yerinde kullanımı gibi etkiler sebebiyle görsel seçiminde Pendik Belediyesi'nin "Uluslararası Folklor Kıyafetleri ve Geleneksel Giysili Ülke Bebekleri Sergisi/2016” katalogundan faydalanılmıştır. Böylece farklı yörelere özgü kıyafetlerin tekrar düzenlenmiş benzer kompozisyonlarının ve net görsellerinin kullanımı, oluşabilecek bilgi ve görüntü karmaşasını önleyerek tasarım öğelerine yön vermiştir.

\subsection{Grafik tasarım}

Türk Dil Kurumunun resmi web sitesine göre grafik; biçim desen veya çizgilerle gösterme olarak tanımlanmaktadır. İletişim sağlama amacıyla kullanılan görsek dil grafik tasarımı oluşturmaktadır. Becer (1997)'e göre grafik tasarımın amacını iletişim ve estetik olarak kaliteyi zirveye taşımak olarak belirtmiştir (s. 33). Bu amaç doğrultusunda mesajın doğru ve etkili iletilebilmesi yalnızca tasarım ilkelerinin bilinerek etkili bir şekilde işlenmesiyle mümkün olabilmektedir. Grafik tasarım en genel anlamda iletişim kurmak amacıyla metin ve görsellerin iki ya da üç boyutlu olarak düzenlenmesini kapsayan yaratıcı bir süreçtir (Çeken ve Ersan, 2016, s. 468).

Sanayi Devrimi sonrası oluşan seri üretim kavramı tüketici alışkanlıklarında değişmelere yol açmıştır. Artan mal ve hizmet arzları sonucunda esnaftan birebir alışveriş yapan tüketiciler bu alışkanlıklarını kaybetmiştir. Buna bağlı olarak üreticilerin ürünlerini topluma duyurma ihtiyacının yanı sıra ürünlerin benzerlerinden farklılaşma gereksinimleri doğmuştur. Bu ihtiyaçların sonucunda hedef kitleye ulaşmak ve ürünleri duyurmak amaciyla reklam faaliyetleri ortaya çıkmıştır. Ürün ve hizmetlere yönelik tanıtım sağlarken talep de uyandırmaya yönelik olan reklam faaliyetleri aynı zamanda tüketici açısından hangi ürünü, nerede ve ne fiyatla bulabileceğine dair bilgilendirici nitelikler taşır (Çeken, Ersan ve Tuğrul, 2018, s. 133).

Görsel iletișim tasarımında hedef kitlenin bilinirliği, pazarın tanımlanması gibi veriler 1şı̆̆ında tasarım ilkelerinin doğru kullanımı tüketicileri etkilemek ve benzer ürünler arasında farklılaşmak için önemli faktörlerdir. İki boyutlu fotoğraf, yazı, renk vb. görsel araçların kullanılarak istenilen mesajın aktarılması grafik tasarım ile mümkündür. Sabah okunan gazeteden yoldaki afişlere ve reklamlara kadar günlük hayatın her köşesinde grafik tasarım iletişimi sağlamaktadır. Ayrıca grafik tasarım, günümüzde gelişen teknolojiyle orantılı bir şekilde gelişim göstermektedir. Baskıdan dijital ortama geçen aktarım boyutunun değişmesi ile uygulanabilirlik ve sunum fikirle birleşmiştir. Web formatındaki gazete ve dergiler, videolu davetiyeler, maille gelen poster ve afişler tüketimin ne kadar hızlandığını göstermektedir. Bu ürün yığını içerisinde farklı olup dikkat çekmek ve dağıtım kanallarını bilerek tasarımı etkili hale getirmek tasarımcının başlıca görevi haline gelmiştir.

\subsection{Endüstriyel ürün tasarımı}

Kullanıcı ihtiyaçlarına yönelik seri üretilmiş nesnelerin yaratımı ile ilgilenen disiplin endüstri ürünleri tasarımıdır. Industrial Designers Society of America (IDSA), endüstri ürün tasarımı tanımını "kullanıcı ve üretici çıkarlarını ortak düzeyde gözeten ürün ve sistemlerin işlev, değer ve görüntülerini en iyi düzeyde yansıtan kavram ve özelliklerin yaratım ve gelişim süreci için yapılan profesyonel hizmet" olarak yapmıştır (Ulrich ve Eppinger, 1995, s. 155).

Bir ihtiyacın oluşması ve buna yönelik problem analizleri yapılarak çözüm yolları bulunması, üretime elverişli olarak geliştirilen bu ürünün son kullanıcı göz önüne alınarak fonksiyonellik, hedef kitle beğenisi ve kullanıcı gereksinimi gibi sınırlılıklar içerisinde yaratımı endüstriyel tasarımı oluşturmuştur.

Fikrin oluşmasından ürünün tüketiciye ulaşması ve ömrünü tamamlaması olarak geçen süre endüstriyel ürünün tasarım sürecini meydana getirmektedir. Endüstriyel tasarım süreci yaratıcılık içeren, birden fazla disiplinle iletişim kurulmasını gerektiren, tekrarlayan ve insan gereksinimi temel alınarak işleyen bir süreçtir (Çevik, 1994, s. 82). 
Araştırma, inceleme, geliştirme, gerçekleştirme ve değerlendirme aşamalarından geçerek pazara sunulma hakkını elde eden ürün ancak başarı firsatını yakalayabilmektedir. Birbiri içerisinde ilerleyen problem çözümü, üretilebilirlik, maliyet düşüklüğü, Pazar analizleri, sunum ve reklam çalışmaları gibi birçok süreç sonunda ürün oluşmaktadır. $\mathrm{Bu}$ süreçlerin birinin eksik ya da yetersiz işlemesi ürünün hedef kitleyi etkilememesi, pazarda başarıya ulaşmaması ve üreticinin zarar etmesi gibi sonuçlara neden olabilmektedir.

\subsection{Tasarımı etkileyen faktörler}

Tüketiciyi satın almaya yönlendiren ambalaj tasarımı gibi endüstriyel tasarım ve grafik tasarımı buluşturan ürünün kabuk tasarımı veya ambalaj tasarımları koruma ve depolama işlevlerinin yanı sıra görsel algıyı ve satışı desteklemelidir. $\mathrm{Bu}$ amaçla beraber ürünün tasarım özelliklerinin ürünü tanımlaması, müşteriyle iletişim kurması, kullanım kolaylığı sağlaması, kullanıcı duygularına hitap etmesi ve rakiplerinden farklılaşması ancak tasarım unsurlarının hedef doğrultusunda etkili kullanımı ile mümkündür. $\mathrm{Bu}$ etkiyi sağlayabilecek ürünlerin sahip olduğu unsurlardan malzeme, biçim, renk, tipografi ve illüstrasyon tanımlanarak tasarımdaki rolü ve pazardaki kullanım yöntemleri incelenmiştir.

a. Malzemenin tasarıma etkisi: seri olarak üretilen piyasadaki ürünler cam, metal, ahşap, plastik gibi birçok farklı malzemeden ve bu malzemelerin kombinasyonlarından meydana gelmektedir. Ürünler için üretim yöntemi, kullanım yeri, dayanıklılık koşulları, saklama ortamları gibi faktörler malzeme seçimini etkileyen başlıca nedenlerdir. Pazarda ürün aileleri için daha fazla tercih edilen klasikleșmiş malzemeler olsa da plastik yerine metal kullanımı gibi kalite ve sağlamlık gösteren malzemeler ürüne değer katmaktadır. Ayrıca bu farklı kullanımlar hedef kitlenin sosyoekonomik yapısına hitap ederek tüketici değer algısını harekete geçirebilmektedir.

b. Formun tasarıma etkisi: Form algıs1, 2 ve 3 boyutlu nesnelerin tüm biçimlerini temsil etmektedir. Ürünlerin form yapısındaki öncelik işlevlerini gerçekleştirmeleri ve kullanım kolaylığı sağlamalarıdır. Bunun gibi depolama, taşıma, yerleşim gibi temel işlevleri yerine getiren ürünler ayrıca estetik olarak da kullanıcıyı etkileme görevine sahiptir. Tüketicinin duygularına hitap edecek, istek yaratacak ve ayırt edici olacak tasarımlar marka için farkındalık yaratmaktadır.

c. Rengin tasarıma etkisi: Renk, nesneleri tanımlamakta kullanılan, insanda duyum ve algılamanın ilk farkındalığını yaratan unsurdur. Araştırmalarda bir ürünün fark edilmesi için geçen 9 saniye içerisinde \%78 oranı ile görme duyumuzun en fazla etkiye sahip olduğunu ve ürün satın alımında rengin $\% 84,7$ oranı ile etkili olduğunu belirtmektedir ("Pazarlamanın", 2004, s. 26-30; "Seoul International", 2004). Yalnızca renk değişimi ile raftaki bir ürün tamamen farklı bir ürün olarak algılanabilir veya aynı ürünün farklı bir özelliği vurgulanabilir. Renkleri insanların davranış ve kararlarını etkileme ve yönlendirme gücüne sahiptir. Bu sebeple ürün tasarımında renk seçimi tüketiciyi satın aldırmakta en önemli faktörlerdendir. Uçar'a (2004) göre, seçme sürecinde renler; ürünü farklılaştıran, bilinirliği kolaylaştıran, ürün sunumunun etkili olmasını sağlayan, dikkat çeken ve duygulara hitap eden etkilere sahiptir. Renklerin ürünlere kattığı karakteristik özellikler ve tüketicide oluşturdukları psikolojik etkiler ışı̆̆ında tasarımda yerinde ve doğru kullanımının ürünü satın almaya, kullanım kolaylığına ve kişisel tatmine ulaştıracağı açıktır (s. 45).

d. Tipografinin etkisi: Müşteri ve ürün arasında iletişimi gerçekleştiren sözsel iletişim unsuru tipografidir. Ürün hakkında bilginin aktarılmasını sağlarken verdiği mesajın öne çıkmasını sağlamaktadır. Ambalajlarda sıkça kullanılan tipografi rengi tamamlayarak markayı desteklemekte ve ürünü kişiselleştirerek hedef kitlesine ulaşmasına yardımcı olmaktadır. Nitekim kitle iletişim araçlarının ve reklam endüstrisinin hızla gelişim göstermesiyle birlikte artık tipografi metin yazısı olmaktan çok, bir tasarım unsuru olarak düşünülmekte ve bu amaca hizmet etmesi için tasarlanmaktadır (Mazlum, 2017, s. 230).

e. İllüstrasyonun tasarıma etkisi: İllüstrasyon yani resimleme, tüm insanların ulaşabildiği ve yararlanabildiği bir sanat dalı olarak tanımlanmaktadır. Ürün ile iletişim kurmaya çalışan insanın resimlemeye dair algısı yaşanmışlıklarına, yaşına, kültürüne göre değişmektedir (Mohajjel Shoja, 2017, s. 43). Ortak bir dil oluşturan sanat, mesajı iletmek için sınırsız bir kaynağa sahiptir. Pazarlamada birçok farklı teknikle uygulanabilen illüstrasyon, mesajların samimi, komik, eğlenceli veya dramatik algılarla tüketiciye ulaşmasını sağlamaktadır. Resimleme ile logo, metin stilleri, sembol, ikon, renk, fotoğraf gibi grafik unsurlarla beraber kullanımı etkin söylemler meydana getirmektedir.

f. Logo: Ürün tasarımının en önemli bileşenlerinden olan logobir markayı temsil eden görsel bir simge, markanın iletişim kurmak için kullandığ bir çeşit işaret sistemidir. Logo, markanın görsel sembolü olan bir amblem ile markanın isminin ayırt edici biçimde bir araya gelmesiyle ya da sadece tipografik öğelerden oluşabilir. Logo, bir markanın özünü ve neyi temsil ettiğini görsel olarak simgeler, markanın temel değerlerini iletir ve markanın hızlıca tanınmasını sağlar (Çeken ve Ersan, 2017, s. 2508) 


\subsection{Pazarlama}

Pazarlama kavramı; bir ihtiyaca yönelik fikrin doğuşu ile başlayarak kullanıcının satın alması ve ürün ömrünü tamamlamasına kadar tüm basamakları içeren bütünsel bir süreçtir. Kotler (2000), 1950'lerden itibaren temel prensipleri oluşmaya başlayan pazarlama kavramını, tüketiciyi ve ihtiyaçlarını iyi tanıyıp kavrayarak bu gereksinimlere yönelik ürünler üretmeyi ve böylece ürünlerin kendi kendisini satmasını amaçlamak olduğunu belirtmiştir (s. 21)

Pazarlamanın yapı taşı olan üretim; süreç içerisinde ihtiyaçların karşılanması amacı ile mal ve hizmetlerin oluşturulması için belirli bir süre içerisinde harcanan çaba olarak tanımlanmaktadır. Hammadde, süreç ve ürün olarak üç aşamadan meydana gelen üretimin asıl amacı insan varlığını sürdürme, gereksinimlerini karşılama ve hayatını kolaylaştırma olarak belirtilmektedir (Öztürk Ahbap, 2014, s. 7). Üretim yönetimi iyi planlanarak başarılı bir üretim stratejisi geliştirilebilirse üretici firmalar için düşük maliyetlerle kaliteli ürünler üretmek başarıyı getirecektir. Bu koşulda üretim süreci ve ürün döngüsü sürekli olarak devam edebilecektir.

İnsanların gereksinimlerini karşılamaya yönelik oluşturulan ve tatmin sağlayan somut ve soyut her şey ürün olarak tanımlanabilmektedir. Pazarlama için bu ürün destinasyon veya yer iken internet veya iletişim kanalları için pazarlanan fikir ürün olarak nitelendirilmektedir (Öztürk Ahbap, 2014, s. 8). Teknoloji gelişimi ile sürekli yükselen hayat standartları sonucu firmalar sürekli yenilenme ve dikkat çekme zorunluluğu içerisindedir. Markaların rakipleri arasında barınabilmek için farklılaşma, çeşitlilik oluşturma, duyulara hitap etme ve kaliteden ödün vermeme gibi özellikler tüketici gözünde güven ve sadakat oluşturması gerekmektedir.

Satış, arz ve talebin kesiştiği yer olarak belirtilmektedir. İşletmelerin mallarını satmak için gösterdiği emek sonucu oluşturulan promosyon ve reklam çalışmaları satış çabası olarak ifade edilmektedir. Satış kavramı, ürünün üretiminden tüketicinin kullanımına sunulmasına kadar geçen tüm süreçlerden oluşmaktadır (Öztürk Ahbap, 2014, s. 9-10). Bu bütüncül süreç içerisinde her hangi bir basamağın eksik olması sonucun kusursuzluğunu etkileyecektir. Kusursuz bir ürün, tüketicisine ulaşamamışsa üretim amacını gerçekleştirememiş demektir. Bu sebeple pazara sunulan ürünlerin duyurulması, rakiplerine göre fayda ve farklarının gösterilmesi gibi tutundurma çalışmaları satışı birebir etkileyen ve kolaylaştıran aşamalardır.

İstek ve gereksinimlerinin farkında olan ve bunları karşılamak için satın alma faaliyetinde bulunan ve aldığ 1 üründen beklediği yarar sonucu ürünü elden çıkaran kişiye tüketici denmektedir. İhtiyacın farkındalığı ile başlayan bu süreç, bu ihtiyacın giderilme güdüsü ile ilerlemektedir (Çakır, 2006, s. 7). Tüketicilerin satın alma davranışlarında satın alma niyeti ile çevre etkileri veya kişisel farklılıklar belirleyici faktörlerdir. Ürün seçimi sırasında haberdar olma, tavsiye edilmesi, reklamların etkisi ve ürünün rakiplere göre farklı özellikler bulundurması gibi tercih sebepleri görülebilmektedir. Günümüzde zorunlu tüketim gibi fonksiyonel faydaların dışında imaj ve semboller içeren duygusal hazların öne çıktığı tüketim tarzları oluşmuştur. Bu sebeple rekabet içerisindeki firmalar ürünü üretmenin yanı sıra ambalajı, servisi, reklamı, teslimatı, avantajlarıyla ürüne değer katma zorunluluğundadır.

Pazardaki değişikliklere uyum sağlama ve ürünün kendini göstermesi gereklilikleri yenilik kavramını gündeme getirmiştir. Pazardaki değişikliklere uyum sağlamak amacıyla ürün ve hizmetlerde yapılan değişime yenilik, firma için ise herhangi bir yenilik taşıyan ürün için yeni ürün tanımı kullanılmaktadır (McCarthy, Jerome ve Perraulant, 1990, s. 289). 1980 yılında ABD'li Booz, Allen ve Hamilton Danışmanlık Firması tarafindan yapılmış çalışmaya göre altı kategoride incelenmiş yenilik çeşitlerinden var olan üründe iyileştirme \%26 ve var olan ürün hattına ilave teknikleri \%26 ile en sık uygulanan yöntemlerdir. Daha az maliyetle daha fazla etki firmaların başlıca hedefidir.

\subsection{Disiplinler arası etkileşim: endüstriyel tasarım-grafik tasarım-pazarlama}

Endüstri ürünleri görsel alg1 nesneleridir yani hepsi duyularla algılanabilir görünüşe sahiptir. Bu görünüşü şekil, renk, desen ve yüzey gibi biçim unsurları oluşturmaktadır. Buna göre her endüstri ürünü estetik işlevselliğe sahiptir (Löbach, 1976'dan aktaran Tunalı, 2002, s. 81). Bu estetik işlev satın alınan ürünün satışını duygusal bağlamda etkileyerek alıcı için hoş veya güzel bulunmasını sağlar.

Grafik tasarım iki boyutlu alanda çalışırken endüstriyel tasarımın alanı üç boyutlu üretimdir. Üretim kavramı etrafında bu iki disiplin ortaklık sağlamaktadır. Daha çok sanatsal algılanan grafik tasarımın bilgi aktarımı yönü ve üretilebilirliği endüstriyel tasarımın seri üretim özelliği ile uyum sağlamaktadır. Ambalaj ve bilgilendirme tasarımı gibi alanlar bu iki disiplinin ortak çalışma bölgeleridir (Akbulut, 2014, s. 29).

Seri üretimle tasarımın buluştuğu yerde görsel farkındalık oluşmaktadır. Estetik ve sanatın kitlesel iletişim ortamları ile geniş bir alana hitap etmesi, sanatın ulaşılabilir bir hale gelmesi pazarlama estetiği kavramını oluşturmuştur. Ürünün işlevsel ve ergonomik özellikleri sağlandıktan sonra estetik ve sembolik değer yaratması, hedef kitleye hitabı ve kalite algısını oluşturması ürünün estetik görünümü ile mümkündür. 
Desmet (2004), ürünlerin duygusal tepkilerini enstrümantal, estetik, sosyal, şaşırma ve ilgi olarak beş kategoriye ayırmıştır. Estetik duyguları, "çekiciliğin değerlendirilmesi", enstrümantal sınıfı "ürüne sahip olma amacı" olarak tanımlamıştır. Bu tutumlar nesnelere ve özelliklerine yönelik beğeni ve beğenmeme durumu olarak açıklanmaktadır (s. 8-12).

Ürüne yaklaşma ya da kaçınma doğrudan ürünün görsel tasarımıyla alakalıdır. Tüketiciler duygusal etkileşim sonucu kendilerine yakın hissettikleri ürünü alma meylinde bulunurlar. $\mathrm{Bu}$ yakınlık bazen bir yazı bazen bir resim bazen de yalnızca renk ile sağlanabilmektedir. Bu özellikler sayesinde ürün daha kaliteli, daha samimi veya daha sağlam algısını yaratabilmektedir. $\mathrm{Bu}$ önyargılar satın alma sırasında oldukça önemli yönlendirmelerde bulunmaktadır.

\section{Yöntem}

Araştırmanın bu bölümünde araştırmanın modeli, evren ve örneklem, veri toplama teknikleri, verilerin analizleri ve yorumlaması, uygulama biçimi açıklanmıştır.

\subsection{Araştırmanın Modeli}

"Yeni Ürün Gruplarının Oluşturulmasında Grafik Tasarımın Etkisi” konusunda betimsel araştırma modeli kullanılmıştır. Benzer konularda yapılan araştırmalar ve piyasadaki örnekler yazılı ve görsel malzeme taraması ile toplanarak incelenmiş ve seçilen ürün grubu olan buzdolaplarının grafik tasarım ile yeni serileri oluşturulmuştur.

\subsection{Evren ve Örneklem}

Araştırma, piyasada seri üretimle meydana getirilip tüketiciye sunulan tüm ürünlerden yola çıkmıştır. Bu sebeple tüketicinin piyasada birebir etkileşimde bulunarak satın alma kararı verebildiği endüstriyel ürünler araştırmanın evrenini oluşturmaktadır.

Bu evrende önem verilen özellik ürünlerdeki görselliğin tüketicilerin tercihinde oynadığı roldür. Piyasada var olan bir ürüne yeni özellik katılması, farklı anlamlar yüklenmesi gibi etkenler dolayısıyla ambalajına veya kabuk tasarımına uygulanan grafik unsurlarla yeniden yaratılan ve tüketiciye yeni bir ürün serisi olarak sunulan ürünler araştırmanın örneklemini oluşturmaktadır.

\subsection{Verilerin Toplanma Teknikleri}

Araştırmada temel olarak ürün tasarımları, pazara sunulma teknikleri, yeni ürün grubu oluşturma stratejileri ve ürünlerde uygulanan grafik tasarımlar gibi konular içeren yayınlar araştırılmıştır. Bu konular ile ilgili piyasada bulunan ürün örnekleri yazılı ve görsel malzeme taraması ile toplanarak değerlendirilmiştir.

\subsection{Verilerin Analizi ve Yorumlanması}

Çalışma kapsamında toplanan ürünler ve grafik uygulamaları incelenerek, ilham kaynakları ve uygulama biçimleri çözümlenmiştir. Buna göre uygulamalarda izlenen yöntemler ve pazar stratejileri analiz edilmiştir.

\subsection{Uygulama}

Tez kapsamında endüstriyel ürünlere uygulanan grafik tasarımlarla oluşturulan yeni serilerin incelenmesiyle elde edilen sonuçlar baz alınarak hazırlanan örnek tasarımlar AdobeIllustrator, Rhinoceros, Keyshot gibi programlar ile görselleştirilmiş ve makalede sunulmuştur. Beyaz eşya ürün grubuna dahil buzdolapları üzerine geleneksel kıyafetler ilham alınarak renk ve motif uygulamaları yapılmıştır. Böylece günümüz beğeni ve eğilimlerine uygun olarak hem kültürel değerlerimizi barındıran hem de pazarlama için ilgi çekici özellikte bir seri oluşturmak amaçlanmıştır.

\section{6. İlgili Araştırmalar}

Pilditch 1961 yılında yazdığı "Sessiz Satıcı" adlı kitapta ambalaj tasarımın pazarlama için önemini vurgulamış ve satın alma kararını önemli oranda etkilediğini belirtmiştir. Gershman ise 1987 yılında ABD'deki üretici firmaların ambalaj tasarımının önemini kavrayarak tasarım ofisleriyle beraber çalıştıklarını belirtmiştir.

Ambalaj tasarımı, pazarlama iletişimi (Underwood, 2003; Underwood ve Klein, 2002; Wood, 2000) ve marka yönetimi (Kapferer, 1997; Shimp, 2001) alanlarında detaylı olarak araştırmalara konu olmuştur.

2000'li yıllardan sonra dünyada olduğu gibi Türkiye'de de ambalaj, araştırmacıların ilgisini çeken bir konu olmuştur. Ürün, yenilik ve sürdürebilirlik gibi alanlarda çalışmalar pazarlama ile doğrudan ilgilidir. Sünnetçioğlu (2006), tasarımda form, boyut, biçim ve renk öğelerinin kullanımının lüks algısı, temalı ürünler ve kaliteli görünüm yaratma sürecini oluşturduğunu savunmuştur. Bahattin (2013) ve Öztürk Ahbap (2014), renklerin pazarlama ile ilgisini inceleyerek müşteriyi etkileme konusunda etkili olduğunu öne sürmüşlerdir. Çınar (2015) ise renklerin yanında tipografi unsurunu da ekleyerek ürünü tanımlayan ve bilgilendiren özellikler olduğunu 
belirtmiştir. Mohajjel Shoja (2017), ambalajlarda illüstrasyon kullanımını ve yaratıcılık barındıran ürünlerin satışı kolaylaştırdığını ifade etmiştir.

Çetinkaya (2008) grafik tasarım ve marka algısını incelerken Güvenir (2014) ürün tasarımı ve markalaşmayı incelemiş ve ürün görünüm, estetik ve anlamlarının markayla bütünleşmesinin tüketici algısına etkilerini vurgulamışlardır. Grafik tasarım ve hedef kitlesi ilişkisine dair yapılan araştırmalarda (Baş, 2014; Akengin, Ersan, Çiçekli ve Tuğrul, 2018) ise tüketiciye yönelik olarak tasarlanan grafik tasarım unsurlarının algısal yönetim sağlayabildiği görüşü ve çeşitliliğin bu kitle farklılıklarına göre oluşturulduğu ortaya konulmuştur.

Ürün ve pazarlama etkileşimi için Kocamaz (2007), ürünün görsel estetiğinin pazarlama iletişiminde farklı sektörler açısından incelemiş ve tüketiciler için değer kavramını oluşturduğunu savunmuştur. Gülerce (2007), Köksal (2008) ve Ülker (2009) ise çağın ihtiyacı olan yenilik kavramını ürünlere yansıtarak tasarım ve teknolojinin birlikte kullanımı ile başarılı sonuçlar elde edileceğini vurgulamıştır.

\section{Bulgular ve Yorum}

Nielsen Durables'ın 2011 yılı Dayanıklı Tüketim Malları Araştırması'na göre beyaz eşya, küçük ev aletleri, elektronik ve kişisel bakım ürünleri arasından Türkiye'de evlerde en fazla bulunan dayanıklı tüketim ürünlerini beyaz eşyalar oluşturmaktadır. Evdeki dayanıklı tüketim mallarının \%36'sı beyaz eşyalardan meydana gelirken yurtiçi pazarında \%10'luk bir oranla buzdolabı satışı diğer beyaz ürünlerin önünde yer almaktadır.

Günümüzde beyaz eşya algısını yıkarak belirgin konseptlerle mutfağın odağı haline gelmeye başlayan buzdolapları çeşitleri çoğalmaktadır. Bu aşamada piyasadaki farklı seri örnekleri incelenerek hangi tasarım unsurlarının daha çok kullanıldığı belirlenmeye başlamıştır. Böylece piyasaya yeni çıkacak ürün tasarımları için belirli konseptler öne sürülebilecek ve geliştirmek için örnek olabilecektir.

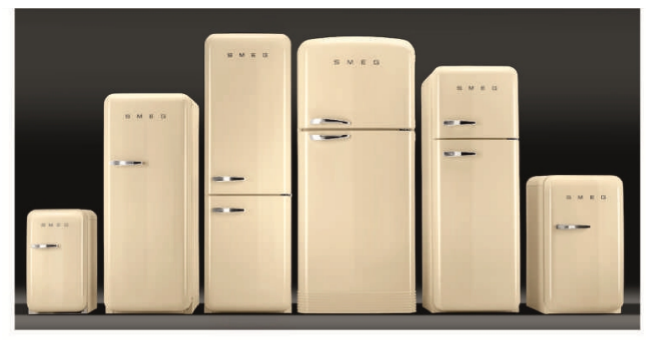

50 's style

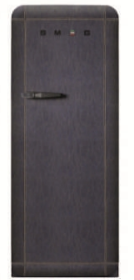

blu denim

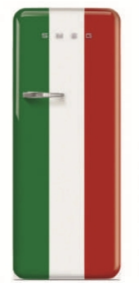

italian flag

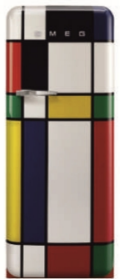

multicolour

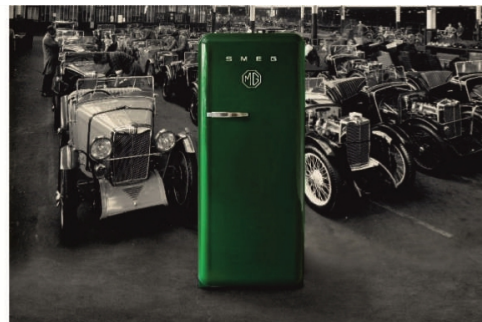

MG ve Smeg

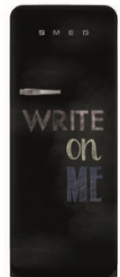

blackboard

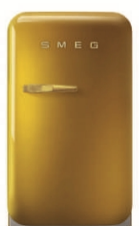

Smeg Gold

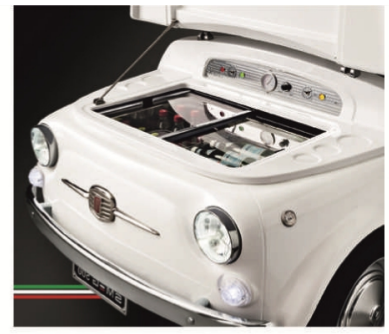

Fiat ve Smeg
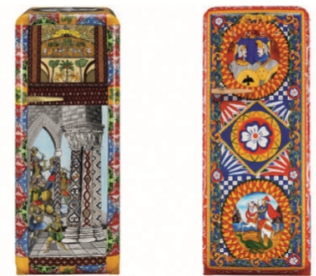

Dolce\&Gabbana ve Smeg

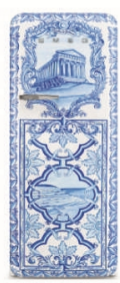

Görsel 1.Smeg buzdolabı serileri

Smeg, 1950’lerinretro tarzı ve canlı renkleriyle öne çıkan, estetik görünümle yüksek performansı birleştirmiş buzdolapları serilerinin en iyi örneklerindendir. Firma, kıvrımlı retro hatlarını andıran formu ve ellilerin parlak renklerine sahip oluşturduğu seri ile mutfaklarda etrafına hakim bir ürün tasarlamayı amaçlamıştır.

İtalyan ve İngiliz bayrağı desenli, Rietveld tarzı renkli blokların kullanıldığı ve çizgili çok renkli kompozisyonları ile renk kullanımlarının öne çıktığı serilere sahiptir. Ayrıca malzeme kullanımları ile dikkat çeken blu denim serisi leke tutmayan kot kumaşı ile kaplanmış ve kara tahta efektli boyaya sahip blackboard serisine sahiptir.

Gold modeli altın rengi ve Swarovski kristalleri kaplanmış kulbu ve logosu ile lüks tüketime yönelik bir üründür. Benzer olarak ikonik markalarla iş birlikleri kurarak yeni seriler oluşturulmuştur. İngiliz motor efsanesi olan MG ile sekizgen rozeti ve İngiliz Yarış Yeşili rengi kullanılarak sınırlı sayıda bir tasarım piyasaya sürülmüştür. Bir başka otomobil firması olan Fiat ile iş birliği yapılarak orijinal araç gövde parçalarının kullanıldığı vintage tarzda özel sipariş ile üretilen Fiat 500 serisi bulunmaktadır. Smeg'in son koleksiyonu ise moda sektöründe bulunan Dolce\&Gabbana ile yapılan Sicilya sanatçılarının el boyama görsellerinden oluşan "Sicily is my Love" (Sicilya benim Aşkım) buzdolabı serisidir. İtalya’ya özgü görsellerin ve renklerin kullanıldığı resimlemelerden oluşan özel bir seridir. 

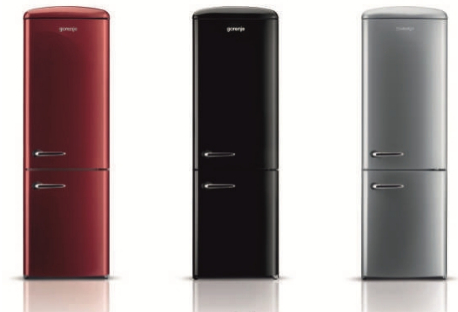

chic
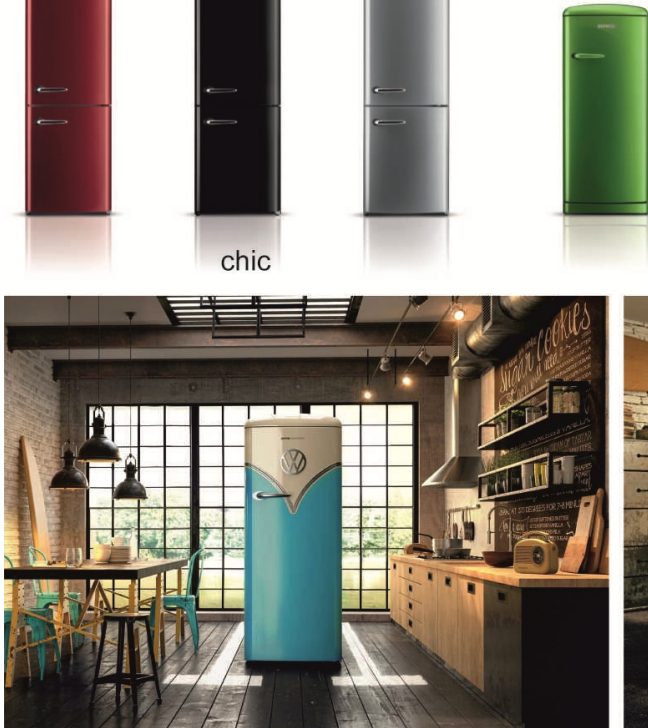

Volkswagen ve Gorenje
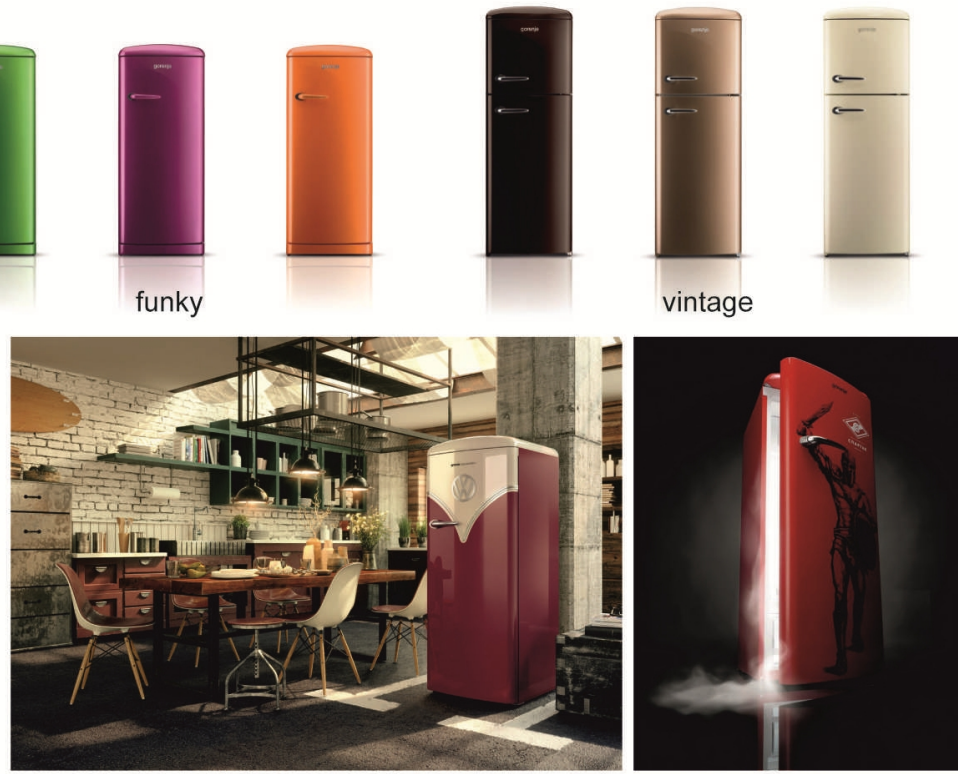

Spartak ve Gorenje

Görsel 2.Gorenje buzdolabı serileri

Retro tasarım serisi üreten firmalardan olan Gorenje, kıvrık hatlarıyla teknolojiyi birleştirerek renkli nostaljik seriler oluşturmuştur. Şık, eğlenceli ve klasik kavramlarla belirlediği üç farklı seri bu konseptleri yansıtan renk tonlarında ve farklı modellerde tasarlanmıştır.

Gorenje'nin retro serisi için Volswagen markası ile iş birliği yapılarak, 1950 ve 60'ların özgür ruhunu sembolize eden ikonik Bulli minibüsünden ilham alınan buzdolabı tasarlanmıştır. Geniş krom kaplama VW logosu bulunduran dolap, krem-bebek mavi ve krem-bordo olmak üzere iki farklı renk seçeneğine sahiptir. Ayrıca firma, yeni bir ülke pazarına girmek içinSpartak Moskova ile iş birliği yaparak kulüp logosu, illüstrasyonu ve kırmızı rengiyle özel seri çıkarmıştır.

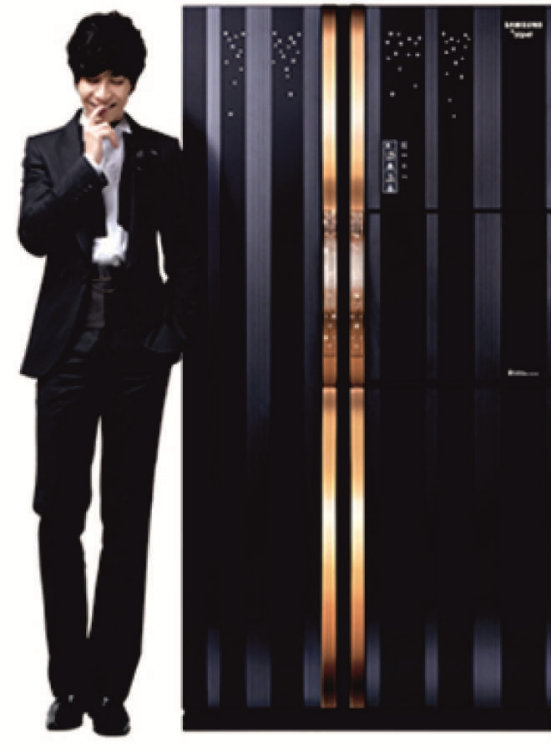

Samsung Zipel side-by-side

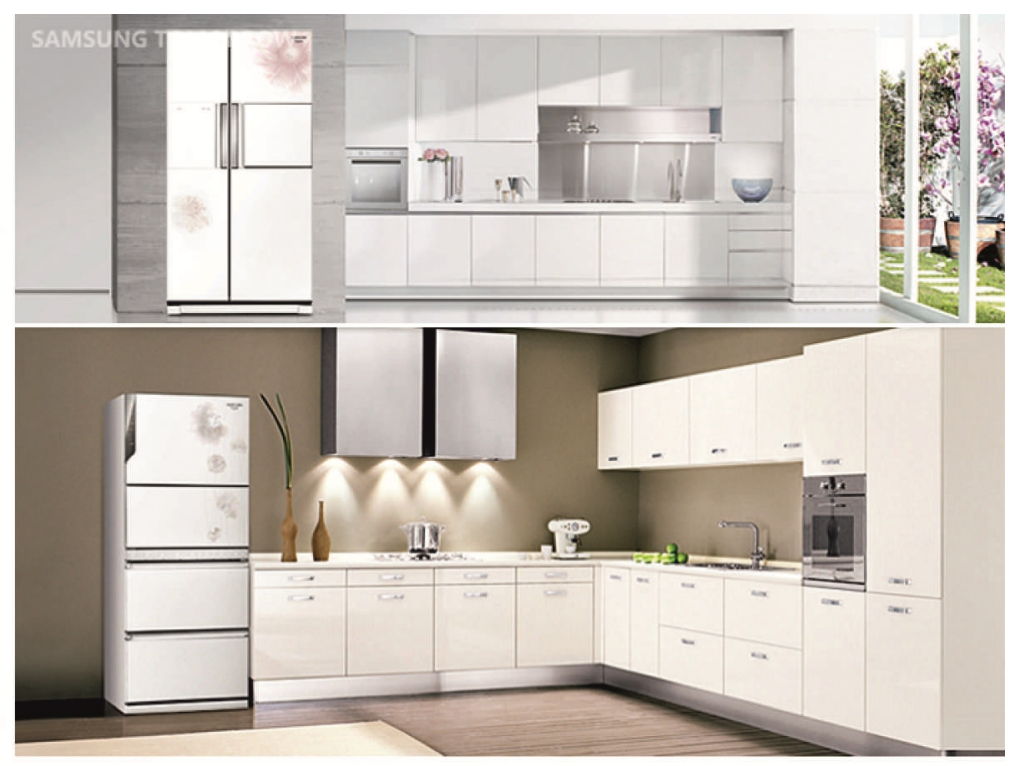

Samsung Zipel Kimchi

Görsel 3.Samsung buzdolabı serileri

General Electric ve Whirlpool gibi markalar tarafindan yönetilmekte olan Kore yerli buzdolabı pazarına Samsung yan yana buzdolabı modeliyle giriş yapmıştır. Hedef kitle analizi ile daha büyük ve çift kapılı bir form seçen firma, Kore'den sonra bu modelini Avrupa pazarına da sunmuştur. Popülerlik kazanan form üst segmentteki tüketiciye hitap edebilmek amacıyla lüks ürün tasarımcısı Massima Zucchi ile anlaşarak mürekkep efektli köye renk kapılara, altın süslemeli şampanya rengi kulplara ve değerli taşlara sahip bir seri üretmiştir. 
Samsung, Kimchi adında geleneksel Kore garnitürü için farklı saklama koşullarını gerektiren ürün gruplarını uygun şekilde muhafaza edebilmek amacıyla belirli sıcaklık ve fermantasyon gereksinimlerini karşılamak üzere Zipel Kimchi serisini tasarlamıştır. Metalik gri ve gülkurusu renkler kullanıldığı sakin, şık bir görünüme ve stilize çiçek resimlemelerine sahip seri pazara özel tasarlanmıştır.
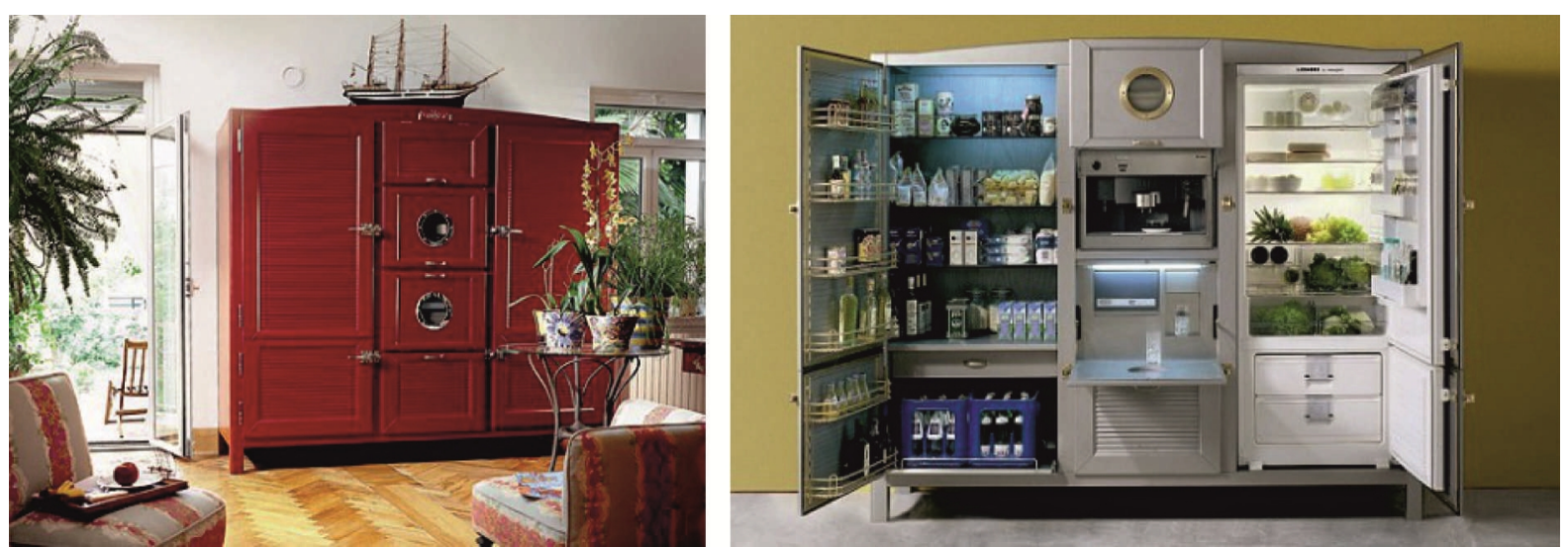

Görsel 4. Meneghini buzdolabı çeşitleri

İtalyan buzdolabı üreticisi Meneghini, kompakt 1 kapılı buzdolabından çok bölmeli 3 kapılı bir versiyona, ek depolama çekmecelerine ve elektronik gömme cihazlara kadar geliştirilebilen kişisel masif ahşap buzdolapları üretmektedir. Ürün imzası olan gemi penceresine sahip bölmesi, firçalanmış metal veya pirinç kulpları ve seçilebilecek sayısız renge sahip La Cambusa serisi, mutfağın merkezine oturacak lüks bir mutfak mobilyası olarak tasarlanmıştır.

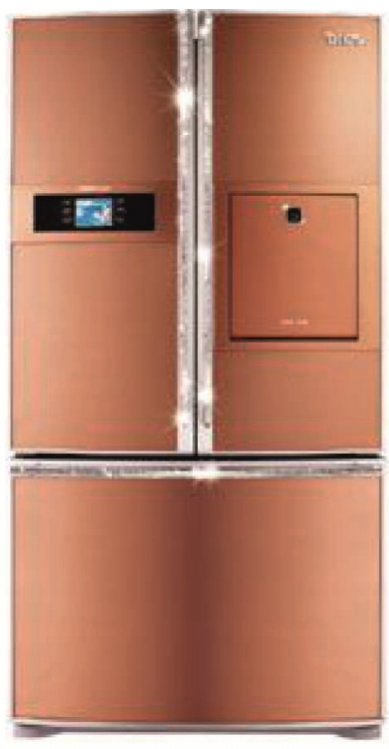

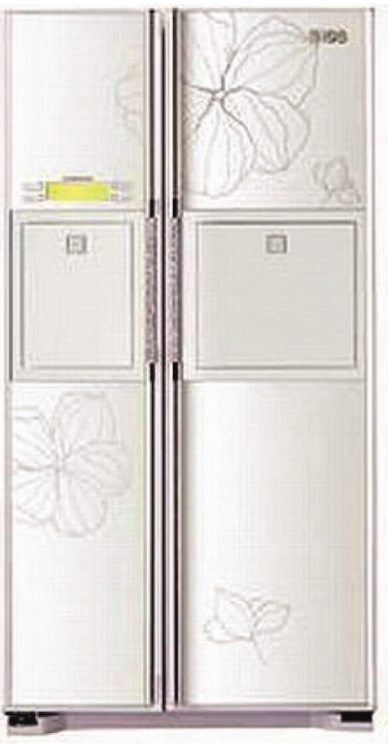

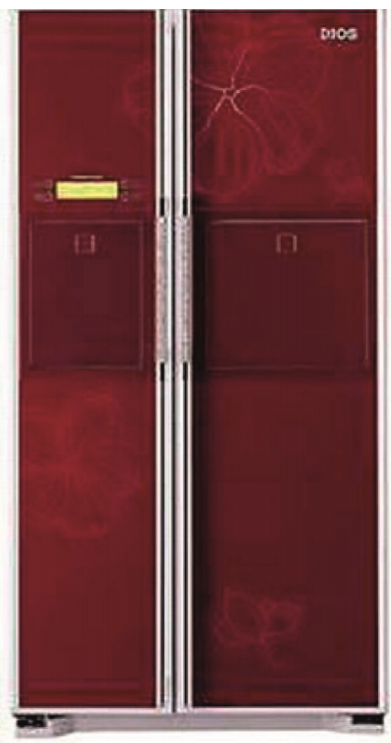

\section{LG DIOS}

Görsel 5. LG buzdolabı serisi

LG, 2005 y1lında Tayvan pazarına özel, buz makinesi ve LCD panel gibi teknolojik özelliklere sahip, üç kapılı dolap kulpunda ve logosunda 4900 adet Swarovski kristali bulunduran sınırlı sayıda bir seri üretmiştir. Işık ve verimliliği temsil eden turuncu rengin parlak ve metalik kullanımı ürünün zengin görüntüsünü ön plana çıkarmıştır. 2008'de piyasaya sürülen iki kapılı modeli ise inci beyazı ve bordo renklerde, stilize çiçek desenleri ve değerli taşlarla bezelidir. 


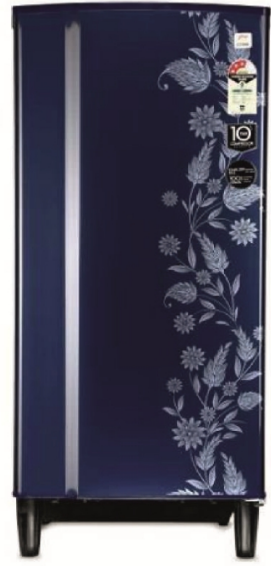

Godrej

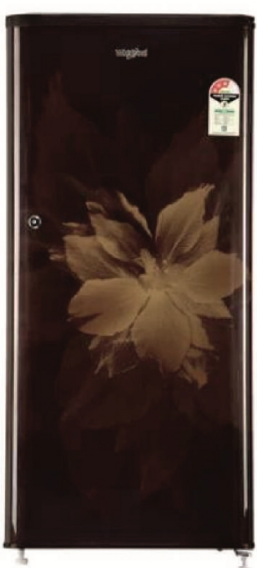

Whirlpool

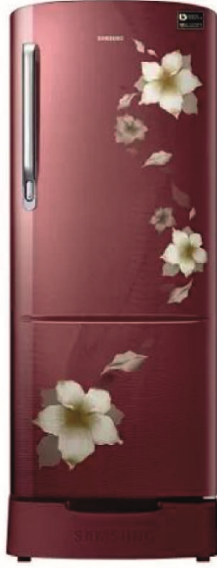

Samsung

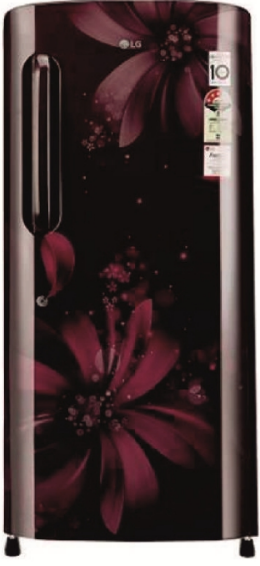

LG

Görsel 6. Hindistan pazarında bulunan buzdolabı serileri

Hindistan pazarında ülkenin dini ritüellerinde bolca kullanılan çiçek figürleri buzdolabı tasarımlarında kendini göstermiştir. Hedef kitlenin beğenisine göre pazara özgü üretilen bu buzdolapları, farklı fïmaların çiçek resimlemelerini çeşitli tasarımlarla yansıtmalarına örnek ürünlerdir. Lacivert, kahverengi, mor ve bordo renk tercihleri firmalara göre değişiklik göstermektedir.

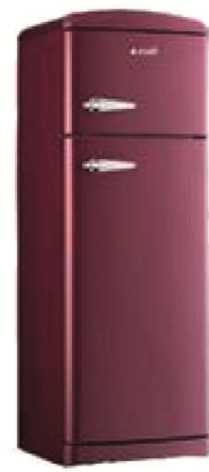

$1955 \mathrm{~K}$

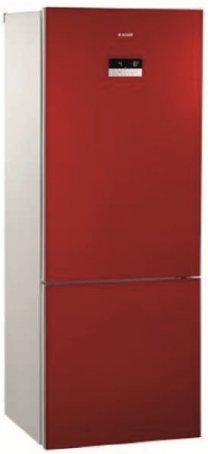

2490 CNG

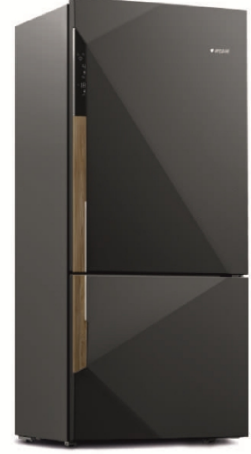

DIAMOND

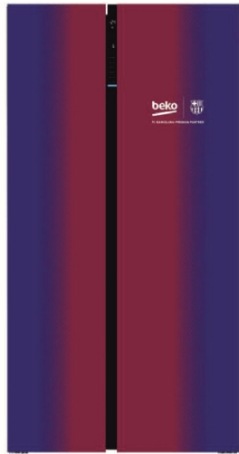

BEKO ve FC BARCELONA

Görsel 7. Arçelik buzdolabı serileri

Arçelik, 1955 yılında çıkardığı buzdolaplarının aynısını bordo ve bej renklerde, kuruluşunun 50.yılına özel nostaljik seri olarak sınırlı sayıda tekrar üretmiştir. 2012'de çamaşır makinelerinde "in love" serisi ile çıkış yapan firma, renkli beyaz eşya olarak teknoloji ve tasarımın birleşmesi kavramıyla Türkiye pazarında yerli firmalara öncü olmuştur. Buzdolaplarında ise 2013 y1lı bordo cam kapılı ürününün ardından 2019 y1lında gövdesinde karbon fiber malzeme kullanılan, ahşap kulplu ve siyah lüks Diamond serisi üretilmiştir. Arçelik'in uluslararası markası olan Beko ise 2016'da FC Barcelona ile iş birliği yaparak cam kapı üzerine takımın renkleri ile Barcelona'nın dünya çapındaki taraftarlarının ilgisini çekmek amacıyla dört farklı model oluşturmuştur.

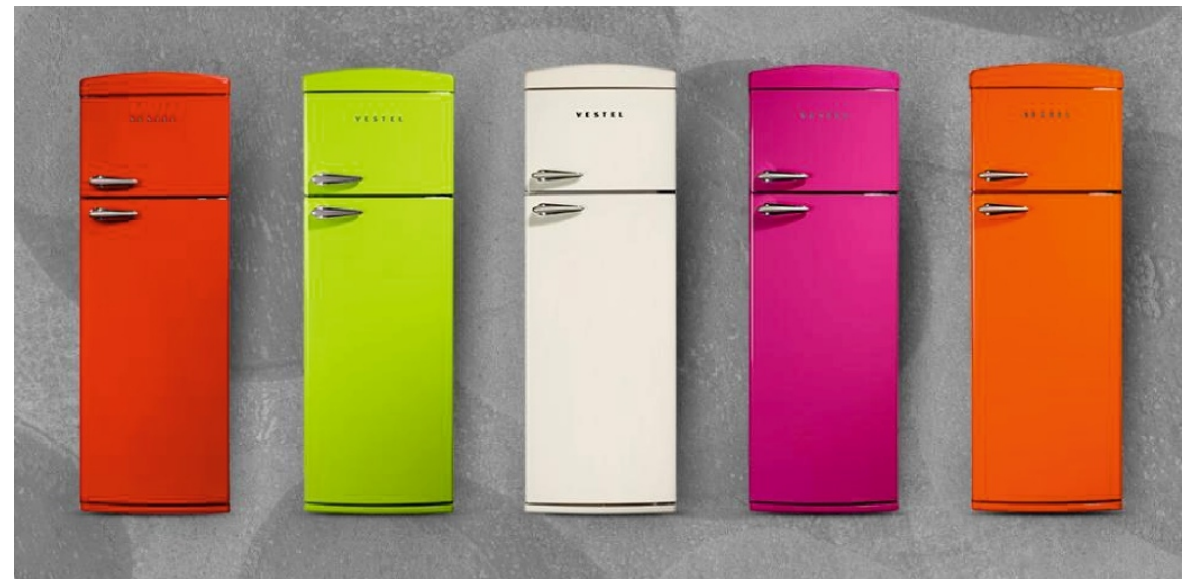

Görsel 8. Vestel "retro" buzdolabı serisi 
Yerli bir marka olan Vestel ise 2013 yılında dört farklı modele altı farklı renk uygulamasıyla retro buzdolabı serisini piyasaya sürmüştür. Kavisli çerçevesi, metal renkli retro kulpları, logo yerleşimi ve canlı renkleriyle genç hedef kitleye nostaljik tasarımda bir seri sunumu amaçlanmıştır. Ayrıca firma hedef kitleye yönelik olarak Kötü Kedi Şerafettin filmine ürünün modeli yerleştirilerek ilgi çeken bir tutundurma çalışmasında bulunmuştur.

\section{Buzdolabında Yeni Seri Oluşturma Uygulaması}

Çalışmada piyasada bulunan beyaz eşya sektöründeki bazı markaların buzdolabı serileri incelenerek bulundurdukları tasarım öğeleri ortaya konulmuştur. Renklerin, etnik desenlerin, bayrakların kullanıldı ̆̆ tasarımlar 1şığında Türkiye için geleneksel desenler uygulanabilir, farklı ve ilgi çekici bulunmuştur. "Anadolu” markası oluşturulmuş ve her bölgeye ait folklor kıyafetleri üzerindeki motifler ve renkler buzdolaplarına aktarılarak farklı seriler oluşturmak amaçlanmıştır. Kıyafetlerin duruşu, rengi ve desenleri göz önünde bulundurularak tasarımsal unsurlar; dolapların tek kapılı, yan yana, dondurucu altta veya kahvaltılık/etlik bölmeli gibi fonksiyonel özellikleri oluşturan formu ile bütünleştirilmiştir.

\subsection{Buzdolabında Yeni Seri Oluşturma Uygulaması}

Anadolu'nun geçirdiği farklı dönemler, çeşitli kültürlerle ilişkisi, tarihi, Orta Asya etkisi, iklim farklılıkları ve tarımsal alışkanlıkları gibi birçok faktör giyim çeşitliliğine ve zenginliğine sebep olmuştur. Yakın tarihe kadar Türk halkının hala giydiği ve günümüzde düğün ve törenlerde kullanılan bu kıyafet ve başlıklar bölgeden bölgeye değişmektedir.

Türk giysilerinin ana parçaları şunlardır (Pendik Belediyesi, 2016, s. 6):

a. İçlik: baştan geçirilen ve belden kuşakla sıkılan gömlek

b. Üstlük: önü açık, kısa kollu veya kolsuz düğmesiz ceket

c. Dizlik: kısa veya çizme içine girecek kadar paçalı pantolon

d. Örme çorap, yumuşak, kısa çizme, koyun postundan külah.

\subsection{Bölge Kıyafetleri ve Seri Uygulamaları}

Akdeniz Bölgesi:
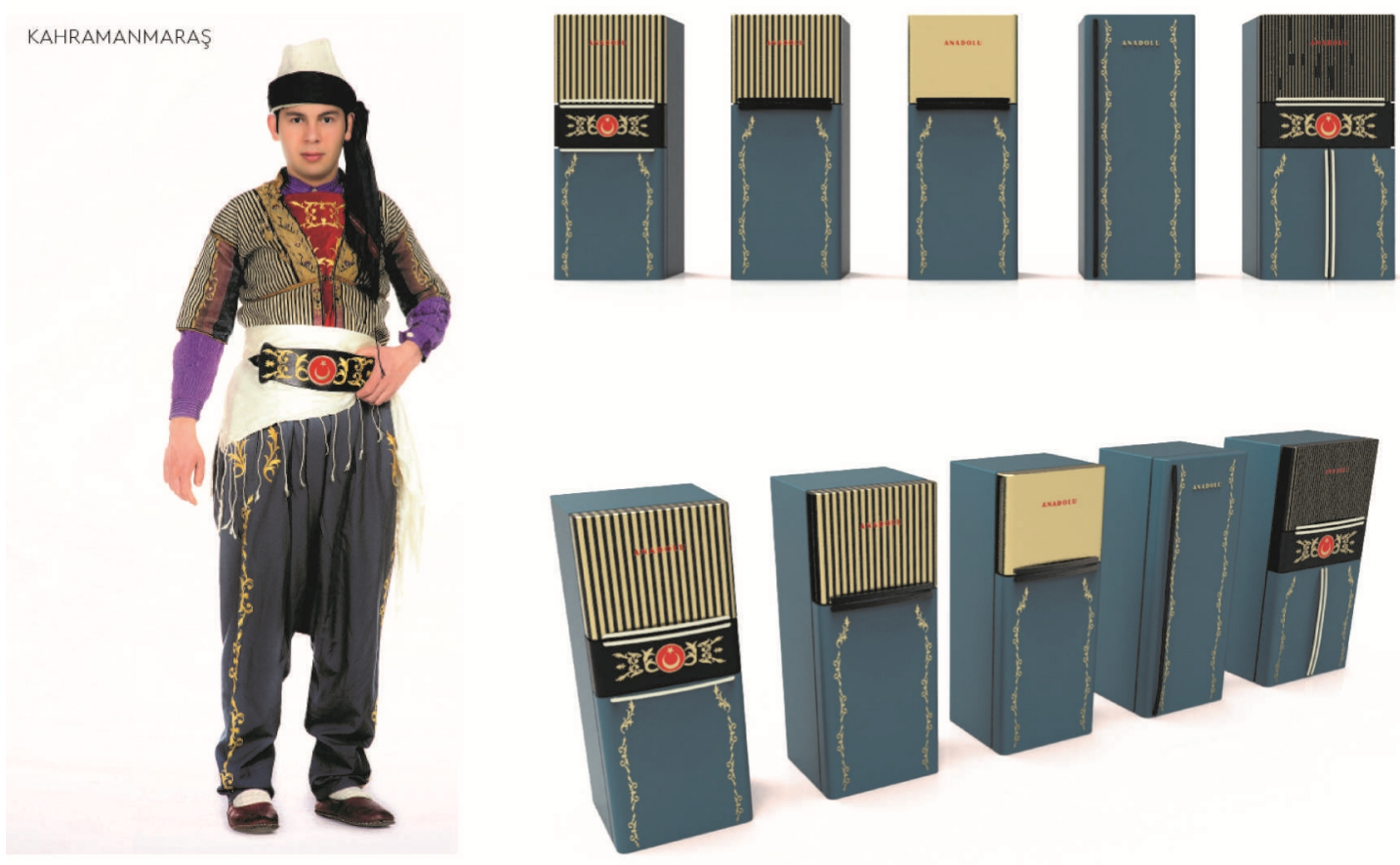

Görsel 9. Kahramanmaraş iline ait geleneksel kıyafet ve Akdeniz Bölgesi için buzdolabı serisi tasarım örnekleri 
Ege Bölgesi:
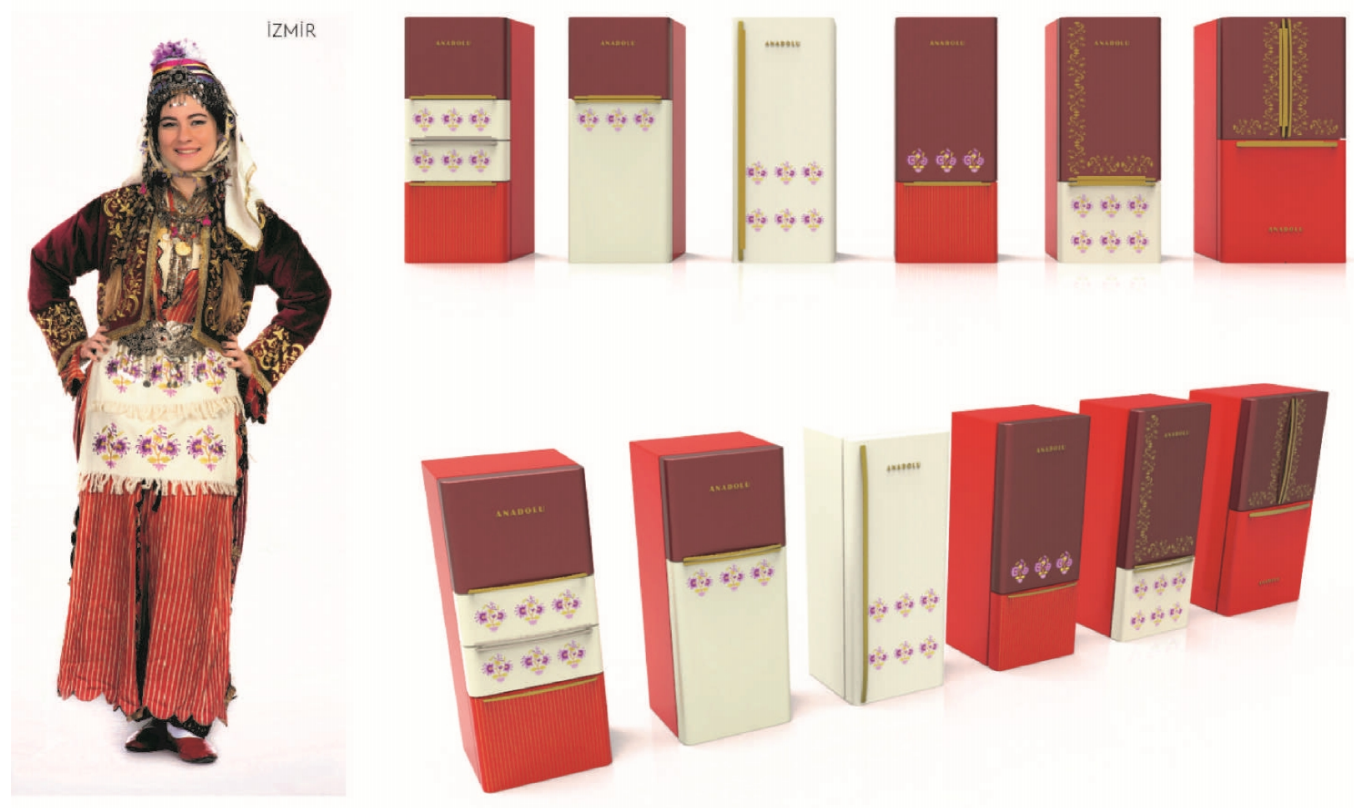

Görsel 10. İzmir iline ait geleneksel kıyafet ve Ege Bölgesi için buzdolabı serisi tasarım örnekleri

Marmara Bölgesi:

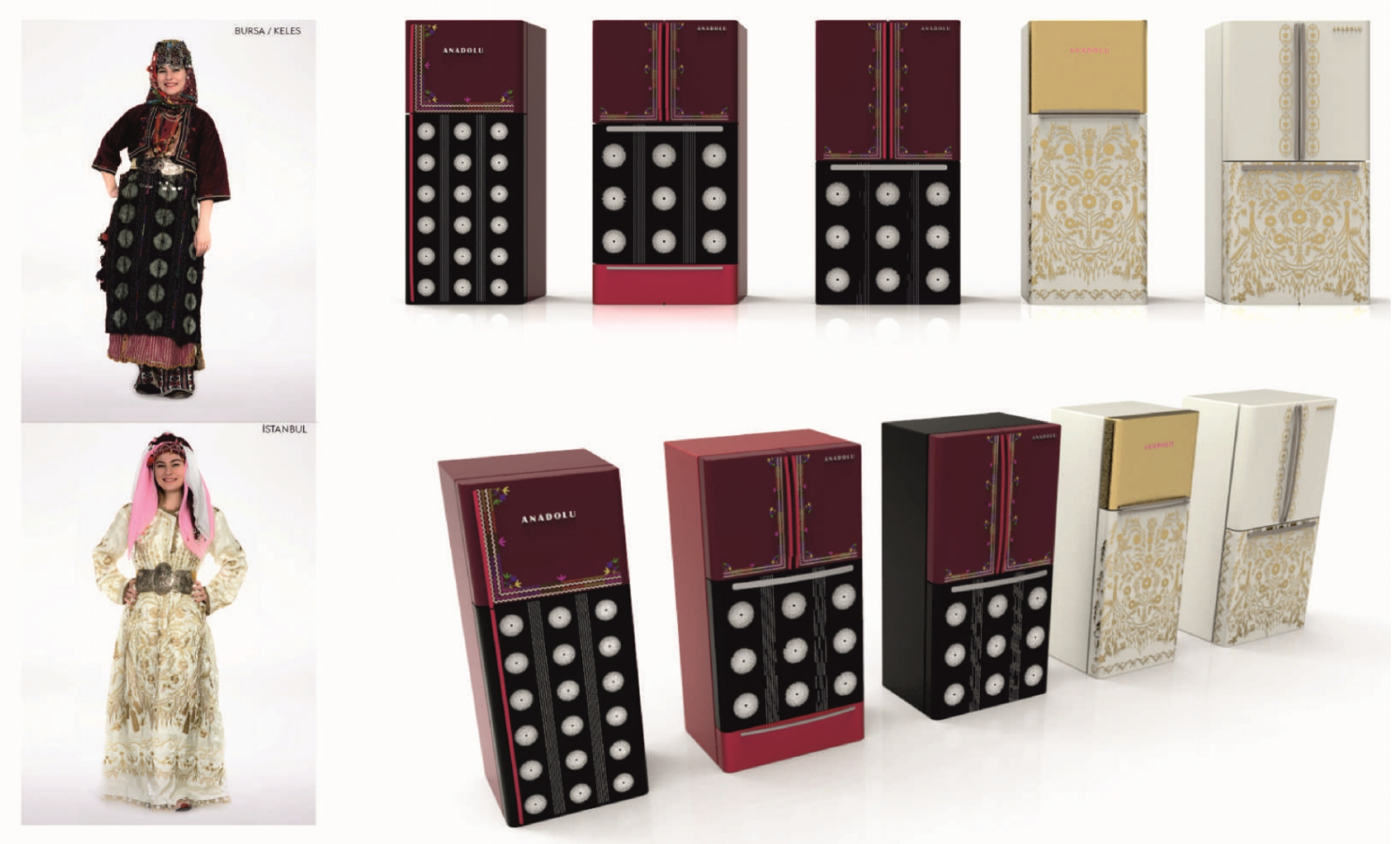

Görsel 11. Bursa ve İstanbul illerine ait geleneksel kıyafet ve Marmara Bölgesi için buzdolabı serisi tasarım örnekleri 


\section{Karadeniz Bölgesi:}
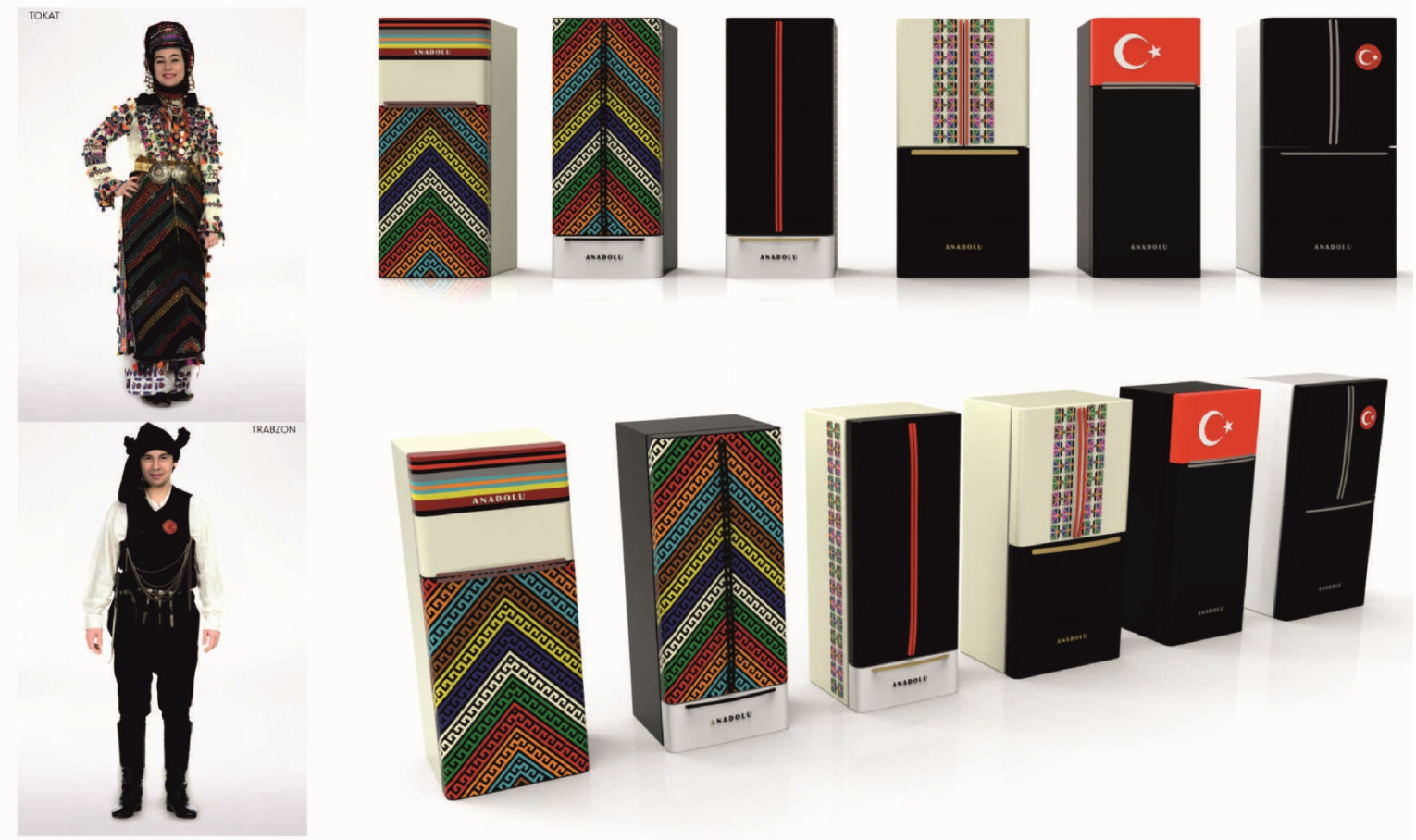

Görsel 12. Tokat ve Trabzon illerine ait geleneksel kıyafet ve Karadeniz Bölgesi için buzdolabı serisi tasarım örnekleri

İç Anadolu Bölgesi:
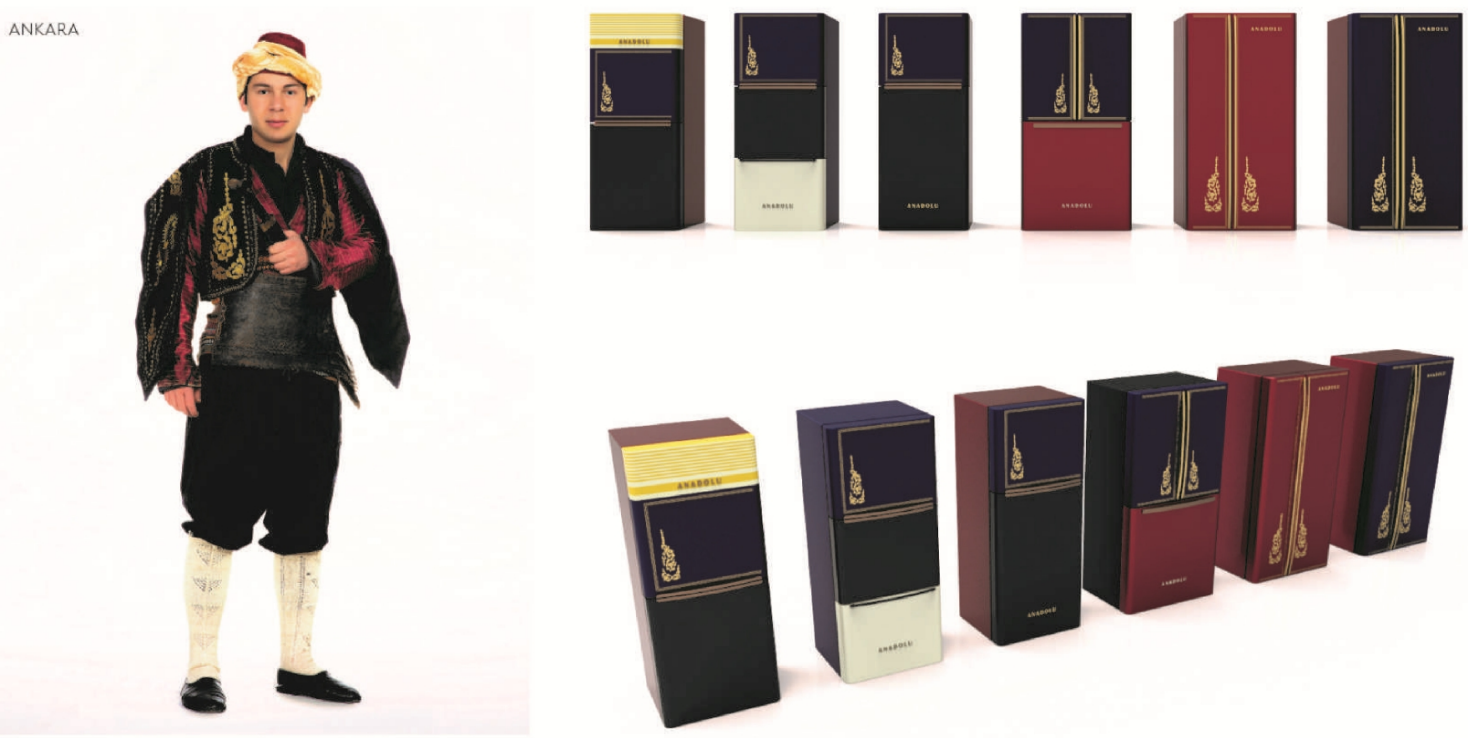

Görsel 13. Ankara iline ait geleneksel kıyafet ve İç Anadolu Bölgesi için buzdolabı serisi tasarım örnekleri 
Doğu Anadolu Bölgesi:
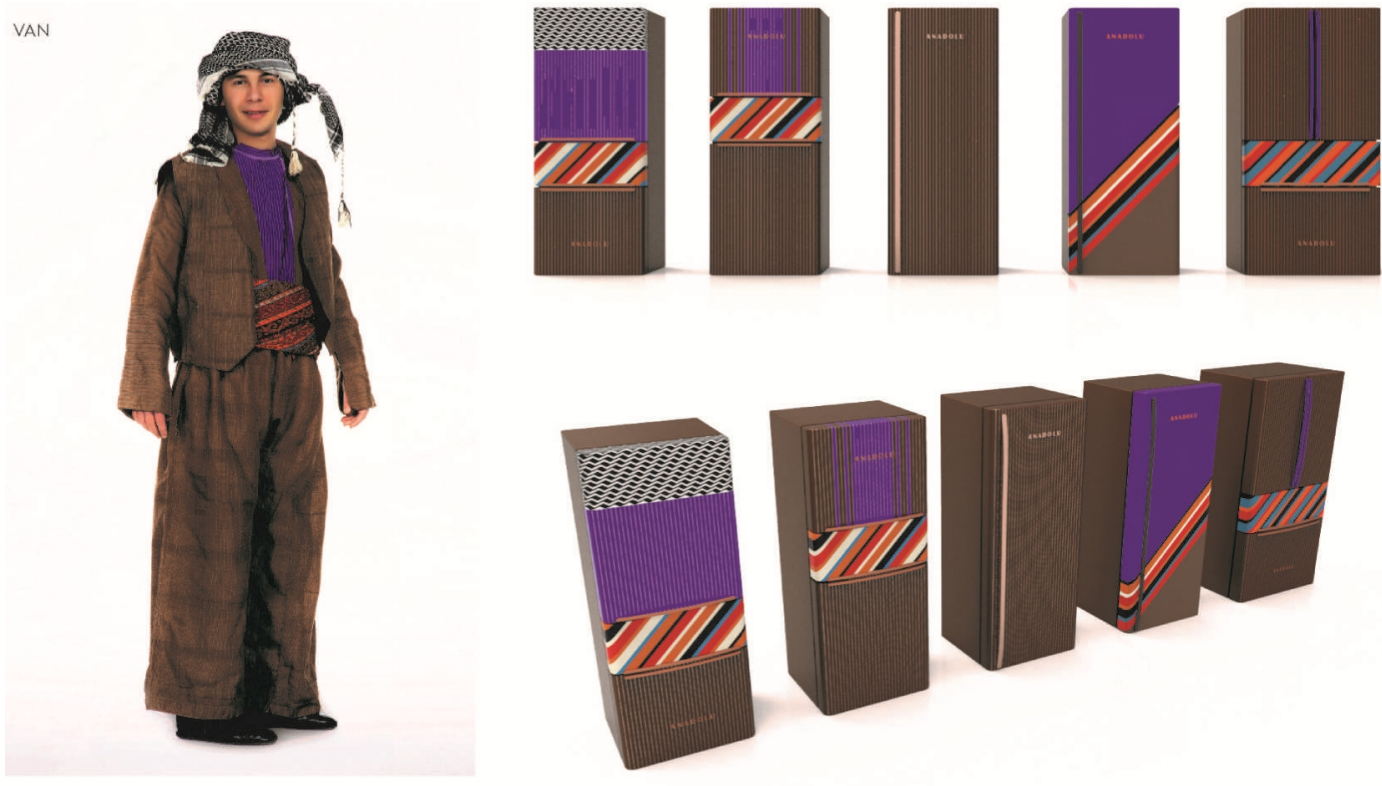

Görsel 14. Van iline ait geleneksel kıyafet ve Doğu Anadolu Bölgesi için buzdolabı serisi tasarım örnekleri

Güneydoğu Anadolu Bölgesi:
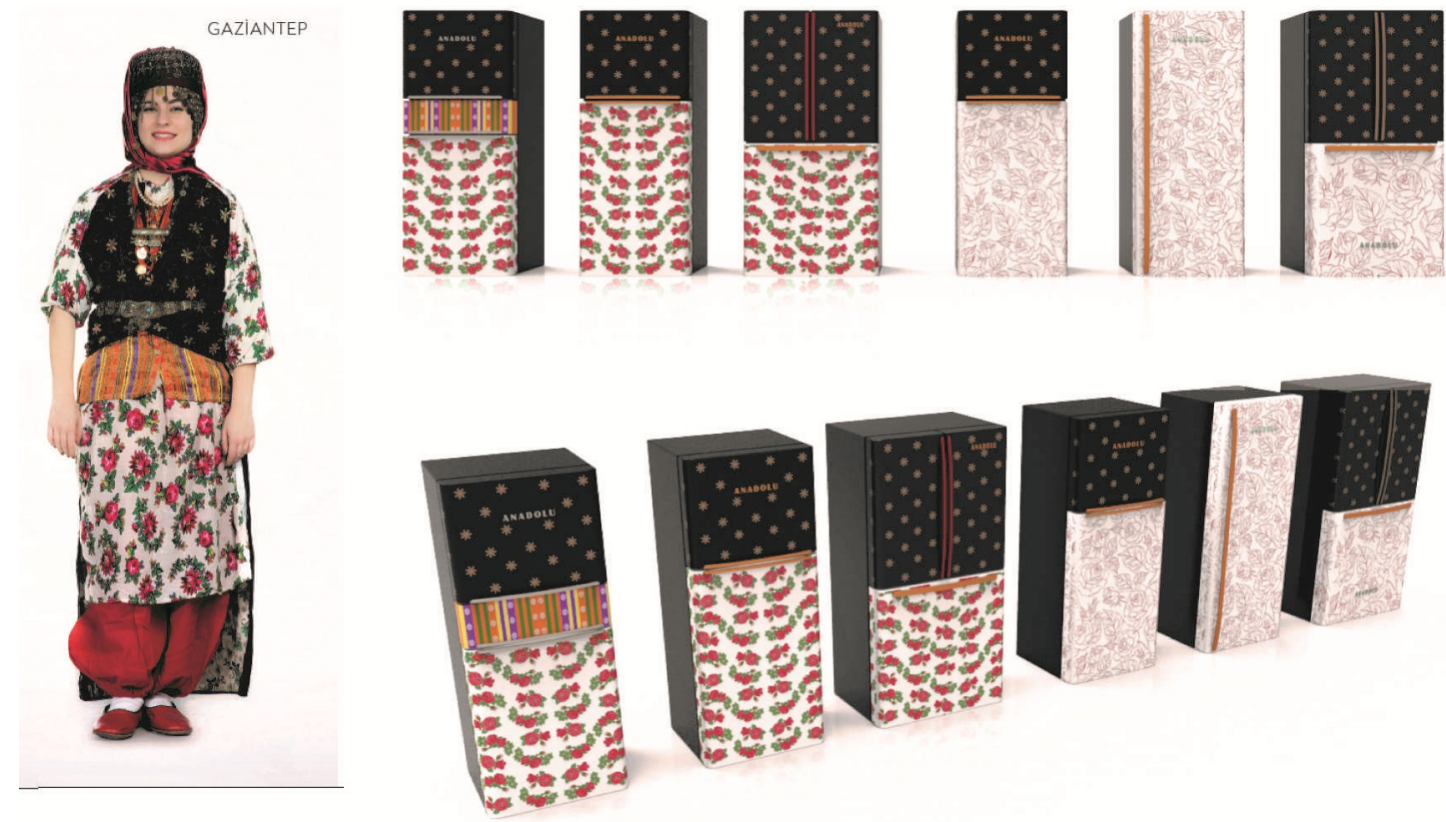

Görsel 15. Gaziantep iline ait geleneksel kıyafet (Pendik Belediyesi, 2016, s. 33) ve Güneydoğu Anadolu Bölgesi için buzdolabı serisi tasarım örnekleri

\section{Sonuç ve Öneriler}

Günümüzde artan rekabet sonucunda her ürün kendini diğerlerinden farklılaștırarak müșterinin dikkatini çekmeye çalışmaktadır. Araştırmada ürün tasarımı, grafik tasarım ve pazarlama özellikleri belirtilerek birbirleri arasındaki etkileşimleri açıklanmıştır. Tüm süreçlerin beraber işlediği ürünlerdeki çeşitlilik ve yarattıkları algılar incelenmiştir. Böylece ürün yaratım sürecinde sorun tespiti ve çözüm bulma aşamasından müşterinin satın almasını sağlamaya kadar geçen süreçte tasarımın pazarlamadaki önemi vurgulanmıştır. Ayrıca müşteri beğenisini kazanmak, dikkat çekmek veya var olan ürünü piyasada tekrar gözde hale getirmek için ürün tasarımlarında grafik tasarımın etkisi örnekler ve uygulamalarla ortaya konulmuştur. 
Ürün tasarlama estetiği, tüketicilerde değer kavramı oluşturmak konusunda çok önemlidir. Kocamaz'ın(2007) sektörel analiz sonuçlarına göre beyaz eşya sektöründe tüketicilerin estetik algısı; tasarımsal farkındalık düzeyine, eğitim seviyesine, cinsiyetine ve gelir seviyesine göre farklılık göstermektedir. Satın alma tercihlerini etkileyen bu faktörler sebebiyle tasarımcılarla pazarlamacılar tüketiciye umduklarından bile fazlasını verebilmek için bütünleşik pazarlama iletişimlerini sağlıklı kurabilmeli ve üretim aşamalarında sıklıkla birlikte çalışabilmelidir. Birçok ayrıntı içeren ürün yaratımı süreci farklı disiplinlere sahip görüşler yardımıyla yeni fikirlerle daha üstün sonuçlar ortaya koyacaktır.

Firmaların piyasaya sürecekleri ürün için yaptıkları pazar analizleri ürünün temel taşını oluşturmaktadır. Pazarlama uzmanlarının geliştirdikleri stratejilerdeki temel prensipler tasarımcılar tarafından bilinerek ürüne yansitılmalıdır. Böylece ürün ile tüketici arasındaki iletişimi sağlayan malzeme, form, renk, illüstrasyon ve tipografi gibi tasarım öğeleri bu stratejiyi destekler nitelikte olup marka için gerekli tasarım kültürünü meydana getirecektir.

Üretim maliyetleri göz önüne alındığında ürün tasarımının farklılaşmasında en başarılı yollardan birinin yeni bir seri oluşturmak olduğu belirtilmiştir. Firmaların yoğun rekabet ortamında bulunmak zorunda oldukları sürekli değişim hali büyük ar-ge ve üretim maliyetlerini gerektirmektedir. Maliyetleri en aza indirerek ürünleri tazelemek amacıyla grafik tasarımdan yararlanarak yeni seriler çıkarmak üretici firmalar için en akıllıca yöntemlerdendir. Bu yöntemler bazen yalnızca slogan eklemek gibi bir öğeyi kapsarken bazen hem malzeme hem renk değiştirmek gibi birçok tasarım öğesini içerebilmektedir.

Buzdolapları üreticileri kendi sektörlerinde moda oluşturan dönemsel çıkışlar yapmakta ve farklı tasarım çizgileriyle sınırlı sayıda üretimler gerçekleştirmektedir. Böylece sektördeki konumlarını tasarımsal olarak sağlamlaştırarak müşteri gözünde bilinirliklerini arttırmaktadır.

Firmalar yeni seri oluşumlarında trendlerden yararlanmalıdır. Moda, ev dekorasyonu, yılın favori renk ve desenleri gibi günümüz eğilimleri tasarım için ilham kaynağı olabilmektedir. Smeg'in örneklerinde bu trendlerden beslenerek buzdolabında yenilikçi seçenekler geliştirmiştir. Kot kumaşı kaplamalı ve kara tahta özelliğinde boyalı buzdolapları bu serilerin yaratıcı örnekleridir.

Beyaz eşyaların malzeme tercihinde kalıpların aşıldığı gözlemlenmektedir. Ev dekorasyonu ile bütünleşen mobilya görünümünde tasarımlar pazarda sağlam bir yere sahiptir. Bu, sektörün yeni tasarımlara açı olduğunu ve dekorasyona beyaz eşyaları dâhil etmenin farklı yolları olduğunu gözler önüne sermektedir.

Grafik tasarım öğelerinden renk, duyguların elçisi olarak ifade edilmekte ve ürünleri farklılaştıran ilk unsurlardan olmaktadır. Pazarlamada renk ve tonlarının seçimi; müşterinin yaşına, cinsiyetine, maddi kazancına, mesleğine ve ürünün kullanım ortamına göre değişiklik göstermektedir. Bu sebeple bir ürün yaratılırken hedef kitlesinin özellikleri ve ihtiyacı araştırılarak sürecin başından ayrıntılı bir şekilde belirlenmeli ve proje bu kapsamda ilerlemelidir.

Buzdolaplarında renk kombinasyonları tüketicilerde belirli algılar oluşturmak için seçilmektedir. Mat ve canlı renkler daha genç kitleye hitap etme amacı taşırken, koyu kırmızı ve siyah gibi renkler daha seçkin, kahve tonları daha romantik algı yaratabilmek için buzdolabı tasarımlarında kullanılmıştır.

Pazarlamada dikkat edilmesi gereken diğer bir etken ise tasarımların farklı kültürlerdeki çağrışımları arasındaki değişikliklerdir. Duyguların farklı renk, sembol, desen ve kelimelerle ifade edildiği toplumlara birebir aynı ürünleri sunmak yerine yapılacak grafiksel değişikliklerle ürünün pazarda tutunması sağlanabilmektedir. Yeni pazarlara girmek için kullanılan taktikler arasında kültürel motifler ve bayrak desenleri bulunmaktadır. Nitekim, küresel pazarda yer kazanmak isteyen kuruluşların tanıtım ve reklam stratejilerinde, faaliyetlerini sürdürdüğü toprakların kültürel değerlerini odak noktaya konumlandırarak var olan kültürel değerlerinden faydalanma ihtiyacı içindedirler (Yılmaz ve Mazlum, 2019, s. 64).

Hedef kitlenin seçiminin ve analizinin pazarda doğru konumlandırmadaki en büyük etkenlerden olduğu görülmektedir. Belirlenen temel stratejilerle ürünün boyut, ergonomi, modülerlik gibi form özellikleri, kullanım alanları, malzeme kalitesi, renk skalası, kullanıcıya seslenen resim, desen ve kelimeleri şekillenecektir. Her bir özelliğin hedefe yönelik tasarlanması ürünün tercih sebebi olarak rakiplerinden sıyrılmasını sağlayacaktır. Bu sebeple tasarımcı bütün özellikleri taşıyan kişiliksiz tek bir üründense, kendinden emin, çözüm odaklı, hitap ve etkileme yeteneği yüksek tasarımlara sahip ürünler meydana getirmelidir.

Farklı hedef kitlesine farklı özellikler sunmada en dikkat çekici kategorilerden biri ise lüks müşteri kitlesidir. Ürünün tarzını koruyarak yeni bir kitleye hitap etmesi tasarım unsurlarının ustaca bir araya getirilmesini gerektirmektedir. Metalik renk seçimleri ve altın, gümüş yaldız kullanımları bu amaçla sıklıkla görülmektedir. Ayrıca tasarımlarda değerli taş kullanımları ve bu taşların üretici firmalarıyla kurulan iş birlikleri lüks kategorinin dikkat çeken sunumlarıdır. 
Yeni seri oluşturma yöntemlerinde öne çıkan diğer bir uygulama ise marka iş birlikleridir. İki firmanın da özelliğini taşıyan ve reklamını yapan bu ürünler başarılı birliktelikler ile oluşursa farklı hedef kitlelerini birleştirebilecektir. Ayrıca bu ürünler yalnızca dönemsel üretileceği için belli bir koleksiyon değeri taşımaktadır. Buzdolaplarında otomobil firmaları, moda evleri ve futbol kulüpleri en dikkat çekici iş birlikleridir.

Yeni ürün gruplarının geliştirilmesine yönelik yapılan bu araştırmanın sınırlılıklarında belirtilmiş olan beyaz eşya sektöründeki buzdolabı ürün grubu kıstası değiştirilerek farklı araştırmalar gerçekleştirmek mümkündür. Böylece ambalajsız satılan ürünler üzerinde grafik tasarımın etkisi farklı ürün grupları veya sektörler arasında karşılaştırılabilir hale gelecektir.

Araştırmanın uygulama aşamasında ise desenlerin ilham kaynağı olarak seçilen geleneksel Türk giysileri konusunun benzer versiyonlarının ürünlere uygulanması ile yeni seriler oluşturmak mümkündür. İklim ve coğrafi özellikler gibi bölgesel ve yöresel konular yeni yapılacak olan araştırmalarda renk ve desen çeşitliliği oluşturabilecek kaynaklar olarak ön görülmektedir.

Tasarımcıların pazarlama stratejilerine uygun adımlar atmaları ve firmaların temel prensipler belirleyerek hedef odaklı çalışmaları tüketiciye sunulan ürünü en yüksek değere kavuşturacaktır. Hep daha fazlasını istemesi güdülenen günümüz tüketicilerinin sürekli olarak değişen ve çeşitlenen ihtiyaçlarını karşılayabilmek ve pazardaki sınırsız ürün sayısı arasından sıyrılabilmek için firmaların en önemli araçlardan biri olan ürün farklılaştırma kavramına yoğunlaşmaları gerekmektedir. Belirlenen hedeflerde ürün tasarımı üzerine grafik tasarım öğelerinin doğru ve dengeli kullanımı müşterinin dikkatini çekecek ve marka sadakatini oluşturacak en temel yöntemlerdendir.

\section{Kaynakça}

Akbulut, D. (2014). Tasarımda temel etkileşim: Temel tasarım eğitiminde bütünleşik ortak zemin. Sanat ve Tasarım Dergisi, 1(13), 23-40. Erişim adresi: https://dergipark.org.tr/tr/download/article-file/192516

Akengin, G., Ersan, M., Çiçekli K. ve Tuğrul D. (2018). Farklı hedef kitlelere göre tasarlanan su şişesi ambalajlarının grafik tasarım açısından incelenmesi. Dumlupınar Üniversitesi Sosyal Bilimler Dergisi, 57, 74-83. Erişim adresi: https://dergipark.org.tr/tr/download/article-file/525602

Bahattin, H. (2013). Tüketicinin satın alma kararı üzerinde ambalaj renklerinin önemi ve grafik tasarım ögrencilerinin konu üzerindeki farkındalığının ölçülmes (Yüksek Lisans Tezi). YÖK tez veri tabanından erişildi. (Tez No. 328853)

Baş, T. (2014). Görsel iletişimde grafik tasarımcının hedef kitle üzerindeki etkisi (Yüksek Lisans Tezi). YÖK tez veri tabanından erişildi. (Tez No. 375368)

Bayazıt, N. (1997). Eczacıbaşı sanat ansiklopedisi, Tasarım Maddesi, Cilt: 3. İstanbul: Y.E.M. Yayınları, s. 1746-1747.

Becer, E. (1997). Illetişim ve grafik Tasarım (10.Bask1). Ankara: Dost Kitabevi.

Çakır, E. (2006). Satın alma kararlarında çocukların rolleri (Yüksek Lisans Tezi). YÖK tez veri tabanından erişildi. (Tez No. 190842)

Çeken, B., \& Ersan, M. (2016). Kişiye özel organizasyonlarda grafik tasarımın yeri. İdil, 5(21), 461-475. doi: https://doi.org/10.7816/idil-05-21-12

Çeken, B., \& Ersan, M. (2017). Ülke markaları: Turizm logolarının tipografik açıdan incelenmesi. İdil, 6(37), s. 2505-2520. doi: https://doi.org/10.7816/idil-06-37-08

Çeken, B., Ersan, M., \& Tuğrul, D. (2018). Market broşürlerinin temel tasarım ilkeleri ve renk kullanımı açısından incelenmesi. Süleyman Demirel Üniversitesi Sosyal Bilimler Enstitüsü Dergisi, 31, 121-137. Erişim adresi: https://dergipark.org.tr/en/download/article-file/557121

Çetinkaya, M. (2008). Tüketiciyi grafik tasarımı ile manipüle etmek: Grafik tasarımın markalaşma ve tüketici algısı üzerinde etkisine dair bir proje (Yüksek Lisans Tezi). YÖK tez veri tabanından erişildi. (Tez No. 226794)

Çevik, O. (1994). Endüstri ürünleri tasarımında üretilebilirlik (Yayımlanmamış Yüksek Lisans Tezi). Marmara Üniversitesi Sosyal Bilimler Enstitüsü, İstanbul.

Çınar, M. S. (2015). Ürün ambalajı tasarımının tipografi ve renk faktörüne yansımaları (Yüksek Lisans Tezi). YÖK tez veri tabanından erişildi. (Tez No. 394724)

Desmet, P. M. (2004). From disgust to desire: How products elicit emotions. Design and Emotion: The Experience of Everyday Things, 1, 8-12. 
Durmaz, Ö. (2009). Hızlı tüketim ürünlerinin ambalaj tasarımlarında çağrışımsal öğrenme ile renk kararları. (Yüksek Lisans Tezi). YÖK tez veri tabanından erişildi. (Tez No. 236037)

Gershman, M. (1987). Packaging: positioning tool of the 1980s. Management Review, August, 33-41.

Gülerce, E. (2007). Yenilenen ambalajın ürün satışına etkisi. II. Uluslararası Matbaa Teknolojileri Sempozyumunda sunulan bildiri, Ankara.

Güvenir, C. (2014). Endüstriyel tasarımda ürün ve marka algısı ve ilişkisi: Bir çikolata markası özelinde anlam bilimsel bir metod uygulaması (Yüksek Lisans Tezi). YÖK tez veri tabanından erişildi. (Tez No. 353772)

Hasdoğan, G. (1996). Tasarım kavramının hukuktaki gelişimi ve endüstriyel tasarımların korunmasına ilişkin ülkemizdeki yasal düzenlemeye yansımaları; Tasarımda evrenselleşme. 2. Ulusal Tasarım Kongresi Bildiri Kitabı (s. 24) içinde. İstanbul: Yem yayınları.

İslamoğlu, A. H. (1999). Pazarlama yönetimi. İstanbul: Beta Yayınevi.

Kapferer, J. N. (1997). Strategic brand management. (3. Edition). Great Britain: Kogan Page.

Karsu, C. (2002). Yeni ürün ticarileştirmesinde stratejik ve taktik pazarlama kararları ve pazarlama iletişimi enstrümanlart sektöründe bir uygulama (Yüksek Lisans Tezi). Marmara Üniversitesi Sosyal Bilimler Enstitüsü, İstanbul.

Kocamaz, İ. (2007). Ürünün görsel tasarım estetiğinin pazarlama iletişimindeki rolü ve beyaz eşya, mobilya ve ev tekstili sektörleri için tüketiciler üzerinde bir uygulama (Yüksek Lisans Tezi). YÖK tez veri tabanından erişildi. (Tez No. 209164)

Kotler, P. (2000). Pazarlama yönetimi (N. Muallimoğlu, Çev.). İstanbul: Beta Basım.

Köksal, A. S. (2008). Pazarlamada yenilik ve uygulama örnekleri (Yüksek Lisans Tezi). YÖK tez veri tabanından erişildi. (Tez No. 226850)

Löbach, B. (1976). Industrial design: Grundlagen D. Industrie produkt gestaltung. Münih: Thiemig.

Mazlum, H. (2017). Modernizm sürecinde yeni tipografi'nin doğuşu ve Jan Tschichold. Kastamonu Üniversitesi İktisadi ve İdari Bilimler Fakültesi Dergisi, 18(1), 226-247. Erişim adresi: https://dergipark.org.tr/en/ download/article-file/361166

McCarthy, E. J., \& Perrault W. D. (1990). Basic marketing. USA: Irwin-Dorsey.

Mohajjel Shoja, M. (2017). Çikolata ve Gıda Ambalajı Tasarımında Resimlemenin Etkileri (Yüksek Lisans Tezi). YÖK tez veri tabanından erişildi. (Tez No. 469204)

Öztürk Ahbap, B. (2014). Renklerin pazarlama üzerindeki etkisi (Yüksek Lisans Tezi). YÖK tez veri tabanından erişildi. (Tez No. 378662)

Pazarlamanın renkli dünyası [Editoryal]. (2004). Marketing Türkiye, 2(46), 26-30.

Pendik Belediyesi. Uluslararası folklor klyafetleri ve geleneksel giysili ülke bebekleri sergisi. 11. Uluslararası Pendik Çocuk Festivali. İstanbul. 19-23 Nisan 2016.

Pilditch, J.(1961). The Silent Salesman. London: Harperand Row.

Seoul International Color Expo. (2004). CCI COLOR,Institute for Color Research.

Shimp, T. A. (2001). Advertising and promotion: Supplemental aspects of integrated marketing communications. (5thedition). US: The Dryden Press.

Sünnetçioğlu, İ. (2006). Kozmetik sektöründe ambalajlamanın rolü ve önemi: Parfüm üzerine geliştirilmiş örnek uygulama (Yüksek Lisans Tezi). YÖK tez veri tabanından erişildi. (Tez No. 189623)

Tunalı, İ. (2002). Tasarım felsefesi (Tasarım modelleri ve endüstri tasarımı). İstanbul: Yem Yayın.

Ulrich, K. T., \& Eppinger, S. D. (1995). Product design and development. NewYork: McCraw-Hill.

Underwood, R. L., \& Klein, N. M. (2002). Packaging as brand communication: Effects of product pictures on consumer responses to the package and brand. Journal of Marketing, 10(4), 58-69.

Underwood, R. L. (2003). The communicative power of product packaging: Creating brand identity via lived and mediated experience. Journal of Marketing, 11(1), 62-77. 
Ülker, D. (2009). Yeni ürünlerde uygulanan tutundurma stratejileri ve bir uygulama (Yüksek Lisans Tezi). YÖK tez veri tabanından erişildi. (Tez No. 249406)

Wood, L. (2000). Brands and brand equity: Definition and management. Management Decisions, 38(9), 662670.

Yılmaz, M., \& Mazlum, H. (2019). Kültürel motiflerin reklam üzerinde kullanımı: Türk Hava Yolları lale motifi örneği. Akdeniz Sanat Dergisi, 13(23), 61-71. Erișim adresi: https://dergipark.org.tr/en/download/articlefile/636897

\section{Görsel Kaynakçası}

Görsel 1. Coloured Refrigerators, (2018). Erişim adresi: https://www.smeg.com/refrigerators/coloured/ adresinden 10 Aralık 2018'de alınmıştır.

Görsel 2. Gorenje Launches a line-up of Spartak Branded Appliances. (15 Kasım 2016). Erişim adresi: https://www.gorenjegroup.com/en/media/news/2016/11/7517-Gorenje-launches-a-line-up-of-Spartakbranded- appliances

Görsel 3. Sales of Samsung's Side-by-Side Refrigerator Top 10 Million. (18 Temmuz 2011). Erişim adresi: https://news.samsung.com/global/sales-of-samsung $\%$ E2\%80\%99s-side-by-side-refrigerator-top-10-million

Görsel 4. Meneghini La Cambusa Fridge for the Ultimate Kitchen. (Ekim 2014). Erişim adresi: https:/italialiving.com/articles/home-garden/meneghini-la-cambusa-fridge-for-the-ultimate-kitchen/

Görsel 5. Swarovski Coated LG Fridges. (25 Haziran 2008). Erişim adresi: https://www.luxuo.com/lifestyle/ gadgets/swarovski-coated-lg-fridges.html

Görsel 6. Top 10 Best Refrigerators Under 15000 in India April 2019. (25 Mart 2019) Erişim adresi: https://www.suggestphone.com/refrigerators/best-refrigerators-under-15000\#LG8

Görsel 7. Buzdolabında 50 y1llık nostalji! (16 Eylül 2006). Erişim adresi: https://www.yuzde100yerli.com/ buzdolabinda-50-yillik-nostalji/

Görsel 8. Eviniz Şimdi Ruhunuz Kadar Renkli. Erişim adresi: https://www.vestel.com.tr/

Görsel 9. Pendik Belediyesi, Uluslararası Folklor Kıyafetleri ve Geleneksel Giysili Ülke Bebekleri Sergisi, 11. Uluslararası Pendik Çocuk Festivali, İstanbul, (19-23 Nisan 2016), Kahramanmaraș İline Ait Geleneksel Kiyafet.

Görsel 10. Pendik Belediyesi, Uluslararası Folklor Klyafetleri ve Geleneksel Giysili Ülke Bebekleri Sergisi, 11. Uluslararası Pendik Çocuk Festivali, İstanbul, (19-23 Nisan 2016), İzmir İline Ait Geleneksel Kıyafet.

Görsel 11. Pendik Belediyesi, Uluslararası Folklor Klyafetleri ve Geleneksel Giysili Ülke Bebekleri Sergisi, 11. Uluslararası Pendik Çocuk Festivali, İstanbul, (19-23 Nisan 2016), Bursa ve İstanbul İllerine Ait Geleneksel Kiyafetler.

Görsel 12. Pendik Belediyesi, Uluslararası Folklor Klyafetleri ve Geleneksel Giysili Ülke Bebekleri Sergisi, 11. Uluslararası Pendik Çocuk Festivali, İstanbul, (19-23 Nisan 2016), Tokat ve Trabzon İllerine Ait Geleneksel Kiyafetler.

Görsel 13. Pendik Belediyesi, Uluslararası Folklor Klyafetleri ve Geleneksel Giysili Ülke Bebekleri Sergisi, 11. Uluslararası Pendik Çocuk Festivali, İstanbul, (19-23 Nisan 2016), Ankara İline Ait Geleneksel Kiyafet.

Görsel 14. Pendik Belediyesi, Uluslararası Folklor Kıyafetleri ve Geleneksel Giysili Ülke Bebekleri Sergisi, 11. Uluslararası Pendik Çocuk Festivali, İstanbul, (19-23 Nisan 2016), Van İline Ait Geleneksel Kiyafet.

Görsel 15. Pendik Belediyesi, Uluslararası Folklor Kıyafetleri ve Geleneksel Giysili Ülke Bebekleri Sergisi, 11. Uluslararası Pendik Çocuk Festivali, İstanbul, (19-23 Nisan 2016), Gaziantep İline Ait Geleneksel Kiyafet. 